\title{
Evidence for microbial iron reduction in the methanic sediments of the oligotrophic southeastern Mediterranean continental shelf
}

\author{
Hanni Vigderovich ${ }^{1}$, Lewen Liang ${ }^{2}$, Barak Herut ${ }^{3}$, Fengping Wang ${ }^{2}$, Eyal Wurgaft ${ }^{1, \mathrm{a}}$, Maxim Rubin-Blum ${ }^{3}$, and \\ Orit Sivan ${ }^{1}$ \\ ${ }^{1}$ The Department of Geological and Environmental Sciences, Ben-Gurion University of the Negev, \\ Beer-Sheva, 8410501, Israel \\ ${ }^{2}$ State Key Laboratory of Microbial Metabolism, School of Life Sciences and Biotechnology, Shanghai, 200240, P.R. China \\ ${ }^{3}$ Israel Oceanographic and Limnological Research, Haifa, 3108000, Israel \\ ${ }^{a}$ The Department of Marine Chemistry and Geochemistry, Woods-Hole Oceanographic Institution, \\ Woods-Hole, MA, USA
}

Correspondence: Orit Sivan (oritsi@bgu.ac.il)

Received: 21 January 2019 - Discussion started: 31 January 2019

Revised: 8 July 2019 - Accepted: 9 July 2019 - Published: 23 August 2019

\begin{abstract}
Dissimilatory iron reduction is probably one of the oldest types of metabolisms that still participates in important biogeochemical cycles, such as those of carbon and sulfur. It is one of the more energetically favorable anaerobic microbial respiration processes and is usually coupled to the oxidation of organic matter. Traditionally this process is thought to be limited to the shallow part of the sedimentary column in most aquatic systems. However, iron reduction has also been observed in the methanic zone of many marine and freshwater sediments, well below its expected zone and occasionally accompanied by decreases in methane, suggesting a link between the iron and the methane cycles. Nevertheless, the mechanistic nature of this link (competition, redox or other) has yet to be established and has not been studied in oligotrophic shallow marine sediments. In this study we present combined geochemical and molecular evidences for microbial iron reduction in the methanic zone of the oligotrophic southeastern (SE) Mediterranean continental shelf. Geochemical porewater profiles indicate iron reduction in two zones, the uppermost part of the sediment, and the deeper zone, in the layer of high methane concentration. Results from a slurry incubation experiment indicate that the deep methanic iron reduction is microbially mediated. The sedimentary profiles of microbial abundance and quantitative PCR (qPCR) of the $m c r A$ gene, together with Spearman correlation between the microbial data and $\mathrm{Fe}(\mathrm{II})$ concentrations in the porewater, suggest types of potential microorganisms
\end{abstract}

that may be involved in the iron reduction via several potential pathways: $\mathrm{H}_{2}$ or organic matter oxidation, an active sulfur cycle, or iron-driven anaerobic oxidation of methane. We suggest that significant upward migration of methane in the sedimentary column and its oxidation by sulfate may fuel the microbial activity in the sulfate methane transition zone (SMTZ). The biomass created by this microbial activity can be used by the iron reducers below, in the methanic zone of the sediments of the SE Mediterranean.

\section{Introduction}

Iron $(\mathrm{Fe})$ is the fourth most abundant element in the Earth's crust. It appears as elemental Fe, Fe(II) and Fe(III) and has an important geobiological role in natural systems (e.g., Roden, 2006). Dissimilatory microbial iron reduction may be one of the first evolutionary metabolisms and plays a key role in the reductive dissolution of $\mathrm{Fe}$ (III) minerals in the natural environment (Lovley and Phillips, 1986, 1988; Lovley et al., 1987; Lovley, 1997; Weber et al., 2006) and in the mineralization of organic matter in freshwater sediments (Roden and Wetzel, 2002). It also serves as a redox wheel that drives the biogeochemical cycles of carbon, nitrogen, sulfur and phosphorous (Li et al., 2012 ; Slomp et al., 2013; Sivan et al., 2014; Egger et al., 2016; Ettwig et al., 2016; Riedinger et al., 2017; März et al., 2018). 
Dissimilatory iron reduction is part of the anaerobic respiration cascade, in which different organic substrates are used for energy by microorganisms and oxidized to dissolved inorganic carbon (DIC). This is accomplished by reduction of electron acceptors, other than oxygen, according to their availability and energy yield. Denitrification is the first respiratory process in anoxic sediments, followed by manganese reduction, iron reduction and then sulfate reduction. Methane $\left(\mathrm{CH}_{4}\right)$ production (methanogenesis) by archaeal methanogens is traditionally considered to be the terminal process of microbial organic matter mineralization in anoxic environments, after the other electron acceptors have been exhausted (Froelich et al., 1979). When the produced methane diffuses away from the methanic layer and meets an electron acceptor it can be consumed by microbial oxidation (methanotrophy). In marine sediments anaerobic oxidation of methane (AOM) coupled to sulfate reduction has been shown to occur (Iversen and Jørgensen, 1985; Hoehler et al., 1994; Hinrichs et al., 1999; Boetius et al., 2000; Orphan et al., 2001; Knittel and Boetius, 2009) and was found to consume up to $90 \%$ of the methane that diffuses upward to the sulfate methane transition zone (SMTZ) (e.g., Neiwöhner et al., 1998; Valentine, 2002).

The classical process of dissimilatory iron reduction is coupled to the oxidation of organic matter (organoclastic iron reduction) (Eq. 1; Lovley, 1991; Lovley et al., 1996). However, iron reduction can be coupled to other processes as well, such as hydrogen $\left(\mathrm{H}_{2}\right)$ oxidation (hydrogenotrophic iron reduction) (Eq. 1; Lovley, 1991). Additionally, Fe(III) can be reduced microbially (and also abiotically) by pyrite oxidation (Eq. 2; Bottrell et al., 2000), leading to sulfur (S) intermediates, and followed by their disproportionation to sulfate and sulfide via a "cryptic" sulfur cycle (e.g., Holmkvist et al., 2011).

$$
\begin{aligned}
& 2 \mathrm{Fe}^{3+}+\text { organic matter } / \mathrm{H}_{2} / \text { humic acids } \rightarrow \\
& 2 \mathrm{Fe}^{2+}+\mathrm{HCO}_{3}^{-} / \mathrm{CO}_{2} / 2 \mathrm{H}^{+} \\
& \mathrm{FeS}_{2}+14 \mathrm{Fe}^{3+}+8 \mathrm{H}_{2} \mathrm{O} \rightarrow 15 \mathrm{Fe}^{2+}+2 \mathrm{SO}_{4}^{2-}+16 \mathrm{H}^{+}
\end{aligned}
$$

Another recently discovered pathway of iron reduction is by $\operatorname{AOM}$ (Eq. 3).

$$
\mathrm{CH}_{4}+8 \mathrm{Fe}(\mathrm{OH})_{3}+15 \mathrm{H}^{+} \rightarrow \mathrm{HCO}_{3}^{-}+8 \mathrm{Fe}^{2+}+21 \mathrm{H}_{2} \mathrm{O}
$$

This process in marine sediments was revealed using incubation experiments with marine seep sediments (Beal et al., 2009; Sivan et al., 2014). It was also suggested to exist in deep sea sediments mainly through geochemical profiles and their modeling (Sivan et al., 2007; März et al., 2008; Riedinger et al., 2014), and also in brackish coastal sediments (Slomp et al., 2013; Segarra et al., 2013; Egger et al., 2014, 2016, 2017; Rooze et al., 2016). In freshwater environments, it was suggested to occur in lakes (Crowe et al., 2011; Sivan et al., 2011; Norði et al., 2013), and in denitrifying cultures from sewage, where it was performed by methanogens (Ettwig et al., 2016). Iron-coupled AOM in natural lake sediments was indicated using isotope porewater depth profiles (Sivan et al., 2011), rate modeling based on these profiles (Adler et al., 2011), microbial profiles (Bar-Or et al., 2015) and directly from a set of sediment slurry incubation experiments (Bar-Or et al., 2017). The few microbial studies on iron-coupled AOM (mainly in cultures) showed either the involvement of methanogenic/methanotrophic archaea (Scheller et al., 2016; Ettwig et al., 2016; Rotaru and Thamdrup, 2016; Cai et al., 2018; Yan et al., 2018) or a cooperation between methanotrophs and methanogens (Bar-Or et al., 2017).

Whereas Fe(II) is highly soluble, Fe(III), which is the most abundant species of iron under natural conditions, appears as low-solubility oxidized minerals. This makes iron usage a challenge to microorganisms, which need to respire these iron-oxide minerals, thus rendering many of the iron-oxide minerals effectively unavailable for reduction and leading to the dominance of sulfate-reducing bacteria beyond a certain depth. Therefore, it is not trivial to observe iron reduction below the upper iron reduction depth, in the methanic zone, where iron-oxides are assumed to be of low reactivity. Moreover, this type of iron reduction is occasionally accompanied by depletion in methane concentrations, suggesting a possible link between the iron and methane cycles. There are three potential mechanisms that can link the cycles: (1) a competition between methanogens and iron-reducing bacteria over substrate, (2) a metabolism switch of methanogens from methanogenesis to iron reduction, and (3) iron-coupled AOM, as mentioned above. Previous observations in other environments demonstrated the inhibition of methanogenesis under iron-reducing conditions due to competition between methanogens and iron-reducing bacteria for the common acetate and hydrogen substrates (Lovley and Phillips, 1986; Roden and Wetzel, 1996; Conrad, 1999; Roden, 2003). Different methanogens can also utilize iron directly, by reducing $\mathrm{Fe}(\mathrm{III})$. This was shown in pure cultures with the amorphous $\mathrm{Fe}(\mathrm{III})$ oxyhydroxide (Bond and Lovley, 2002), in pure cultures close to natural sedimentary conditions (Sivan et al., 2016), in natural lake sediments with different iron oxides (i.e., amorphous iron, goethite, hematite and magnetite) (Baror et al., 2017), in anoxic ferruginous lake sediment enrichments (Bray et al., 2018) and in iron-rich clays (Liu et al., 2011; Zhang et al., 2012, 2013).

Despite the above studies, the nature of the link between the biogeochemical cycles of iron and methane in the methanic zone of marine sediments, which creates suitable conditions for iron reduction, has not yet been determined. Furthermore, this microbial iron reduction in methanic zones has not been shown in the sediments of oligotrophic shallow marine environments. In this study we report the observation of microbial iron reduction in the methanic depth of marine sediments from the oligotrophic southeastern (SE) Mediterranean continental shelf. The microbial iron reduction is observed by using geochemical porewater profiles, 
Table 1. Cores sampling details: dates, water depths and locations.

\begin{tabular}{|c|c|c|c|c|}
\hline Date & Station & $\begin{array}{c}\text { Water } \\
\text { depth } \\
\text { (m) }\end{array}$ & Latitude & Longitude \\
\hline \multirow[t]{2}{*}{14 August 2013} & PC-5 & 87 & $32^{\circ} 55.47^{\prime}$ & $34^{\circ} 54.01^{\prime}$ \\
\hline & PC-3 & 81 & $32^{\circ} 55.29^{\prime}$ & $34^{\circ} 54.14^{\prime}$ \\
\hline 6 February 2014 & PC-3 & 82 & $32^{\circ} 55.30^{\prime}$ & $34^{\circ} 54.14^{\prime}$ \\
\hline 18 January 2015 & PC-3 & 82 & $32^{\circ} 55.30^{\prime}$ & $34^{\circ} 54.14^{\prime}$ \\
\hline 9 June 2015 & SG-1 & 89 & $32^{\circ} 57.87^{\prime}$ & $34^{\circ} 55.30^{\prime}$ \\
\hline 17 September 2015 & SG-1 & 84 & $32^{\circ} 57.91^{\prime}$ & $34^{\circ} 55.27^{\prime}$ \\
\hline 24 January 2017 & SG-1 & 85 & $32^{\circ} 57.51^{\prime}$ & $34^{\circ} 55.15^{\prime}$ \\
\hline
\end{tabular}

quantitative PCR (qPCR) profiles (of archaea, bacteria and the $m c r A$ functional gene) and 16S rRNA gene sequencing profiles at three different stations, combined with a simple slurry incubation experiment from the methanic zone. The slurries were amended with hematite and magnetite. Given their low reactivity these are the $\mathrm{Fe}(\mathrm{III})$ minerals expected to survive the sulfide zone (Canfield, 1989; Poulton et al., 2004). Furthermore, these minerals were found to be active in iron-coupled AOM in lake sediments (Bar-Or et al., 2017). The profiles, the incubation experiment and the related microorganisms are discussed in terms of the possible links between the cycles of iron and methane.

\section{Methods}

\subsection{Study site}

The surface water in the Levantine Basin of the SE Mediterranean Sea, including Israel's continental shelf, is an oligotrophic nutrient-poor marine system (Herut et al., 2000; Kress and Herut, 2001). The continental shelf narrows from south to north and is composed of Pliocene-Quaternary Nilederived sediments. The sedimentation rate decreases with increasing distance from the Nile Delta and from the shoreline (Nir, 1984; Sandler and Herut, 2000). Off the shore of Israel, the sediment accumulation rate is relatively high at $\sim 0.1 \mathrm{~cm} \mathrm{yr}^{-1}$ (Bareket et al., 2016). The bottom seawater along the continental shelf is well oxygenated and sulfate concentrations at the water-sediment interface are $\sim 30 \mathrm{mmol} \mathrm{L}^{-1}$ (Sela-Adler et al., 2015). The central and eastern regions of the Levantine Basin have relatively low total organic carbon (TOC) content $(\sim 0.1 \%-1.4 \%$; AlmogiLabin et al., 2009; Sela-Adler et al., 2015; Astrahan et al., 2017) as compared to the Western Mediterranean Basin and offshore the Nile River delta ( $1 \%-2 \%)$. Along the Egyptian coast, the TOC in surface sediments on the shelf reach maximum values of $1.5 \%$ (Aly Salem et al., 2013). The finding of a free gas zone, which is located from a few meters to tens of meters below the seafloor (i.e., gas front), in seismic profiles within the sediments of the continental shelf of Israel (Schattner et al., 2012), led to the discovery of biogenic methane

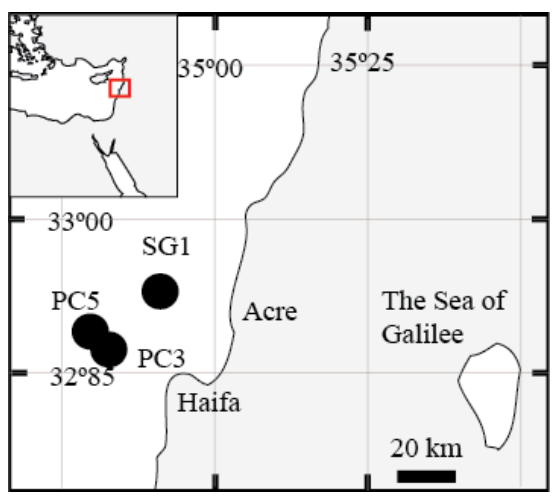

Figure 1. A map of the study area with the location of the three stations that were sampled SG-1, PC-3 and PC-5 (map created by Eyal Wurgaft).

formation at some locations in the shallow sediments (SelaAdler et al., 2015).

\subsection{Sampling}

Seven sediment cores ( $\sim 5-6 \mathrm{~m}$ long) were collected using a Benthos 2175 piston corer, from the undisturbed sediments of the SE Mediterranean continental shelf of Israel at water depths of 81-89 m from three stations; SG-1, PC-3 and PC-5 (Fig. 1). The cores were sampled during cruises of the RV Shikmona between 2013 to 2017, and by the RV Bat-Galim on January 2017 (Table 1). The sediment cores were sliced on board every $25-35 \mathrm{~cm}$ within minutes upon retrieval from the seafloor. This area was previously investigated for other purposes, such as the sulfate reduction in the SMTZ (Antler et al., 2015; Wurgaft et al., 2019), and the possibility for methanogenesis (Sela-Adler et al., 2015).

From each interval, a $2.5 \mathrm{~mL}$ of sediment sample was collected and inserted immediately into an anoxic $10 \mathrm{~mL}$ glass bottle filled with $5 \mathrm{~mL} \mathrm{NaOH} 1.5 \mathrm{~N}$ for headspace measurements of methane concentration (after Nüsslein et al., 2003). Approximately $3 \mathrm{~mL}$ of sediment was sampled every $50 \mathrm{~cm}$ for porosity. In addition, another $2.5 \mathrm{~mL}$ sediment sample was taken from each segment of the cores and transferred into a $20 \mathrm{~mL}$ glass bottle filled with a $\mathrm{NaCl}$-saturated solution for $\mathrm{H}_{2}$ concentration measurements. Sediment samples from each segment of the cores were centrifuged on board if possible or in the lab within a day by Sorval centrifuge at $9299 \mathrm{~g}$ under $4{ }^{\circ} \mathrm{C}$ and $\mathrm{Ar}$ atmosphere in order to extract porewater for chemical analysis. The supernatant was filtered $(0.22 \mu \mathrm{m})$ and analyzed for $\mathrm{Fe}(\mathrm{II})$, sulfate, sulfide, DIC and the stable carbon isotope composition of the DIC $\left(\delta^{13} \mathrm{C}_{\text {DIC }}\right)$. After the porewater extraction, the sediment was analyzed for the content of the different reactive iron minerals. In addition, a sediment subsample from each segment of the January 2017 core from Station SG-1 was kept at $-20^{\circ} \mathrm{C}$ for molecular analysis. Due to high water content and movement in the uppermost part of the sediments, two $\sim 30 \mathrm{~cm}$ sediment 
Table 2. Experimental setup of the slurry incubation experiment.

\begin{tabular}{lc}
\hline Treatment & Number of bottles \\
\hline Hematite & 2 \\
Magnetite & 2 \\
Hematite $+\mathrm{H}_{2}$ & 2 \\
Magnetite $+\mathrm{H}_{2}$ & 2 \\
Killed + hematite $+\mathrm{H}_{2}$ & 2 \\
Killed + magnetite $+\mathrm{H}_{2}$ & 1 \\
\hline
\end{tabular}

cores were also subsampled separately, using a $0.0625 \mathrm{~m}^{2}$ box corer (Ocean Instruments BX $700 \mathrm{Al}$ ) and Perspex tubes, during the September 2015 and January 2017 cruises. The short cores were stored at $4{ }^{\circ} \mathrm{C}$ and cut in the lab within $24 \mathrm{~h}$ after their collection, and their results are presented for the top sediment (Fig. 2a-d).

\subsection{Slurry incubation experiment}

The experimental setup (Table 2) consisted of 11 bottles with sediment from the methanic zone $(265-285 \mathrm{~cm}$ depth) from Station SG-1, where iron reduction was apparent from the porewater profiles (Fig. 2d). Prior to the beginning of the experiment, sediment from the designated depth had been homogenized in an anoxic bag under $\mathrm{N}_{2}$ atmosphere. It was then transferred under anoxic conditions to a $250 \mathrm{~mL}$ glass bottle with the addition of synthetic seawater without sulfate to reach a $1: 1$ sediment: water slurry ratio for a 3-month incubation period. After the incubation period the slurry was subdivided anoxically to the 11 experiment bottles $(60 \mathrm{~mL}$ each), and synthetic seawater was added for a final sediment: water ratio of $1: 3$. The bottles were sealed with a crimped cap and were flushed with $\mathrm{N}_{2}$ for $5 \mathrm{~min}$, shaken vigorously and flushed again, (repeated 3 times). Three experimental bottles were autoclaved twice to serve as "killed" control for the experiment. The experimental bottles were amended with $1.6 \mathrm{~g} \mathrm{~L}^{-1}$ of hematite $\left(\mathrm{Fe}_{2} \mathrm{O}_{3}\right)$ or $2.3 \mathrm{~g} \mathrm{~L}^{-1}$ of magnetite $\left(\mathrm{Fe}_{3} \mathrm{O}_{4}\right)$ to reach $\mathrm{Fe}$ (III) final concentration of $10 \mathrm{mmol} \mathrm{L}^{-1}$. The three killed bottles were amended with the iron oxides after they cooled down to room temperature. $\mathrm{H}_{2}$ was added to some treatments to test its potential as an electron donor. A total of $1 \mathrm{~mL}$ of $\mathrm{H}_{2}$ was injected by a gastight syringe to the three killed bottles, to two bottles with the addition of hematite and to two bottles with the addition of magnetite (to reach a final concentration of $\sim 4 \%$ of the head space volume). The experimental bottles were sampled several times for dissolved Fe(II) concentrations during the $14 \mathrm{~d}$ experiment period.

\subsection{Analytical methods}

\subsubsection{Porewater analyses}

Methane concentrations in the porewater were analyzed with a focus gas chromatograph (GC; Thermo) equipped with a flame ionization detector (FID) with a detection limit of $50 \mu \mathrm{mol} \mathrm{L}{ }^{-1}$. To calculate the methane concentrations the sediment porosity was considered. Porosity was determined by drying wet sediment samples at $60^{\circ}$ until there was no weight loss $(\sim 48 \mathrm{~h})$. It was calculated as the weight loss from the initial weight of the samples. $\mathrm{H}_{2}$ concentrations were analyzed in a reducing compound photometer gas chromatograph (RCP-GC; Peak Laboratories). Dissolved Fe(II) concentrations were measured using the ferrozine method (Stookey, 1970) by a spectrophotometer at $562 \mathrm{~nm}$ wavelength with a detection limit of $1 \mu \mathrm{mol} \mathrm{L}{ }^{-1}$. Sulfide was measured using the Cline (1969) method by a spectrophotometer at $665 \mathrm{~nm}$ wavelength with a detection limit of $1 \mu \mathrm{mol} \mathrm{L}{ }^{-1}$. Total sulfur concentrations were measured in an inductively coupled plasma atomic emission spectrometer (ICP-AES), from Perkin Elmer Optima 3300, with an analytical error of $\pm 1 \%$ (average deviations from repeated measurements of a seawater standard). Since sulfide was not detected in any of the sediment cores, the total sulfur concentration in each porewater sample was assumed to be the sulfate concentration of that sample. The $\delta^{13} \mathrm{C}_{\mathrm{DIC}}$ values were measured on a DeltaV Advantage Thermo ${ }^{\odot}$ isotope-ratio massspectrometer (IRMS) at a precision of $\pm 0.1 \%$. Results are reported versus VPDB standard. Porewater profiles of dissolved total sulfur, $\mathrm{CH}_{4}, \delta^{13} \mathrm{C}_{\text {DIC }}, \mathrm{Fe}$ (II) and $\mathrm{H}_{2}$ were produced during the study, and all of them are presented (Fig. 2). For each profile where duplicate samples were taken the error bar is that of the average deviation of the mean of the duplicates; in cases where only single samples were taken, it is the analytical error (if larger than the symbol).

\subsubsection{Sediment analysis}

Reactive $\mathrm{Fe}$ (III) in the sediments was measured according to the Poulton and Canfield (2005) definition and sequential extraction procedure. The different reactive iron minerals were separated to (1) carbonate-associated $\mathrm{Fe}\left(\mathrm{Fe}_{\mathrm{carb}}\right)$ (i.e., siderite and ankerite), (2) easily reducible oxides $\left(\mathrm{Fe}_{\mathrm{ox} 1}\right)$ (i.e., ferrihydrite and lepidocrocite), (3) reducible oxides $\left(\mathrm{Fe}_{\mathrm{ox} 2}\right)$ (i.e., hematite, goethite and akageneite) and (4) magnetite $\left(\mathrm{Fe}_{\mathrm{mag}}\right)$. Sediment samples were dried at $60^{\circ}$, and then approximately $0.6 \mathrm{~g}$ dry sediment was inserted to a centrifuge tube with $10 \mathrm{~mL}$ of a specific extractant at every stage under atmospheric conditions and constant agitation (Table 3). The fluids were separated from the sediment by centrifugation and removed from the tube with a Pasteur pipette after every extraction stage. At the end of each extraction stage, the extractant was transferred to a $15 \mathrm{~mL}$ falcon tube with $0.1 \mathrm{~mL}$ ascorbic acid and $0.1 \mathrm{~mL}$ ferrozine solution to reduce all the 
$\mathrm{Fe}(\mathrm{III})$ to $\mathrm{Fe}(\mathrm{II})$ and fix it, and then it was measured spectrophotometrically. The results presented as "total reactive $\mathrm{Fe}$ (III)" are the sum of $\mathrm{Fe}_{\mathrm{ox} 1}, \mathrm{Fe}_{\mathrm{ox} 2}$ and $\mathrm{Fe}_{\mathrm{mag}}$. The profile of pyrite $\left(\mathrm{Fe}_{\mathrm{py}}\right)$ was taken from Wurgaft et al. (2019).

\subsubsection{Quantitative PCR and 16S rRNA gene V4 amplicon pyrosequencing}

DNA was extracted from the sediment core of Station SG1 from January 2017 using a Power Soil DNA Kit (MoBio Laboratories, Inc., Carlsbad, CA, USA) following manufacturer's instructions. Copy numbers of selected genes were estimated with qPCR as described previously (Niu et al., 2017) using specific primers: Uni519f/Arc908R and bac341f/519r for archaeal and bacterial 16S rRNA genes, respectively, and mlas/mcrA-rev for the mcrA gene, which encodes the $\alpha$ subunit of methyl-coenzyme $\mathrm{M}$ reductase. The amplification efficiency was $94.5 \%, 106.3 \%$ and $92.4 \%$ for the archaeal 16S rRNA, bacterial 16S rRNA and the $m c r A$ gene, respectively (the respective $R^{2}$ of the standard curve was 0.998 , 0.998 and 0.995).

The V4 regions of bacterial and archaeal 16S rRNA genes were amplified using barcoded 515FB/806RB primers (Walters et al., 2015) and Arch519/Arch806 primers (Song et al., 2013), respectively. PCR mixture contained 6-10 ng total DNA, $5 \mu \mathrm{L} 10 \times$ Ex Taq buffer, $4 \mu \mathrm{L} 2.5 \mathrm{mmol} \mathrm{L}^{-1} \mathrm{dNTP}$ mix, $1 \mu \mathrm{L}$ of each primer, $0.25 \mu \mathrm{L}$ Ex Taq polymerase (ExTaq; TaKaRa, Dalian, China) and $5 \mu \mathrm{L}$ bovine serum albu$\min \left(25 \mathrm{mg} \mathrm{mL}^{-1}\right)$ in a total volume of $50 \mu \mathrm{L}$. DNA was sequenced as $2 \times 150$ base pair reads using an Illumina MiSeq platform (Illumina, USA). Sequence quality assessments, chimera detection and down-stream phylogenetic analyses were conducted in QIIME (Caporaso et al., 2010). Taxonomical assignments for each OTU were performed in QIIME using the BLAST method and the SILVA128 reference database. A total of 24056 to 132042 high-quality sequences were obtained per sample, with the proportion of highquality sequence versus total sequence between $81.97 \%$ and $99.89 \%$. A Spearman correlation was performed using the online calculator (http://www.sthda.com/english/rsthda/ correlation.php, last access: 20 October 2018) to test the relevance of microbial abundance and communities with Fe(II) concentration along the depth of the sediment core from $185 \mathrm{~cm}$ to the bottom $575 \mathrm{~cm}$, which is the methanic zone of the sediment core according to the geochemical profile (see the results below).

\section{Results}

\subsection{Geochemical profiles}

Geochemical porewater profiles of several sediment cores from the three stations (SG-1, PC-3 and PC-5; Fig. 1, Table 1) were produced in order to characterize the iron reduction process in the methanic zone of the SE Mediterranean continental shelf and to identify its potential sources. The porewater profiles at Station SG-1 (Fig. 2a) show complete depletion of total sulfur at approximately $150 \mathrm{~cm}$ depth in all cores. Sulfide concentrations were below the detection limit in all cores, indicating that the total sulfur is mostly sulfate. The methane concentrations in the porewater (Fig. 2b) show an increase with depth immediately after the consumption of sulfate. The maximum methane concentration was approximately $10 \mathrm{mmol} \mathrm{L}^{-1}$ at $\sim 140 \mathrm{~cm}$ depth in June 2015 . The other methane depth profiles show an increase in the concentrations to approximately $2 \mathrm{mmol} \mathrm{L}^{-1}$ and then leveling off throughout the bottom of the cores $(\sim 600 \mathrm{~cm})$. Detected dissolved Fe(II) concentrations (Fig. 2d) were found in the upper iron reduction zone (between 30 and $90 \mathrm{~cm}$ depth), and a second peak was found in the deeper part of the sediment, at the methanic zone (below $180 \mathrm{~cm}$ depth). Maximum dissolved $\mathrm{Fe}$ (II) concentrations reached $84 \mu \mathrm{mol} \mathrm{L}^{-1}$ in the upper iron reduction zone of the sediments and $65 \mu \mathrm{mol} \mathrm{L}^{-1}$ in the methanic zone. The $\delta^{13} \mathrm{C}_{\text {DIC }}$ values (Fig. 2c) were the lowest $(-35 \%)$, as expected at the SMTZ depth, and the highest in the methanic zone. $\mathrm{H}_{2}$ concentrations (Fig. 2e) decreased to a minimum of $0.017 \mu \mathrm{mol} \mathrm{L}^{-1}$ at $155 \mathrm{~cm}$ depth and then increased to a maximum of $0.147 \mu \mathrm{mol} \mathrm{L}^{-1}$ at $485 \mathrm{~cm}$ depth.

Porewater profiles from Station PC-3 (Fig. 2g-1) show similar patterns to Station SG-1 on all three sampling dates, but with lower methane concentrations. Total sulfur (Fig. 2g) was completely depleted within the upper $300 \mathrm{~cm}$ depth. Sulfide concentrations were below the detection limit at this station as well. Methane profiles show an increase in methane concentration immediately after the consumption of sulfate. The maximum methane concentration (Fig. 2h) reached $0.8 \mathrm{mmol} \mathrm{L}^{-1}$ at $450 \mathrm{~cm}$ depth in the core from August 2013. The dissolved Fe(II) profiles (Fig. 2j) show two peaks at this station as well, one in the upper part of the sediment with a maximum value of $32 \mu \mathrm{mol} \mathrm{L} \mathrm{L}^{-1}$ at $177 \mathrm{~cm}$ depth, and another one with a maximum value of $64 \mu \mathrm{mol} \mathrm{L}^{-1}$ at $390 \mathrm{~cm}$ depth at the methanic depth. The $\delta^{13} \mathrm{C}_{\text {DIC }}$ values (Fig. 2i) decreased from approximately $-10 \%$ at the water-sediment interface to $-20 \%$ at the SMTZ. Below that zone there was an increase in $\delta^{13} \mathrm{C}_{\mathrm{DIC}}$ values to about $-5 \%$ due to methanogenesis. $\mathrm{H}_{2}$ concentrations (Fig. $2 \mathrm{k}$ ) remained around $2 \mu \mathrm{mol} \mathrm{L}^{-1}$ along the core. The three deviating points that do not fit the clear pattern are attributed to an analytical or sampling error.

Porewater profiles from the core collected at Station PC-5 (Fig. S1) resemble the profiles of Station PC-3. Total sulfur was depleted at approximately $300 \mathrm{~cm}$, and methane concentrations increased below that depth to $0.3 \mathrm{mmol} \mathrm{L}^{-1}$. The $\mathrm{Fe}(\mathrm{II})$ profile shows two peaks in this core as well, one in the upper sediment of $20 \mu \mathrm{M}$ at $150 \mathrm{~cm}$ depth and the second of $30 \mu \mathrm{mol} \mathrm{L}-1$ in the methanic zone. The $\delta^{13} \mathrm{C}_{\text {DIC }}$ value decreased from $-5 \%$ at the water-sediment interface to $-25 \%$ at the SMTZ, and below that depth increased to $-17 \%$ in the methanic zone. 
Table 3. Summary of reactive iron extraction procedure (after Poulton and Canfield, 2005).

\begin{tabular}{|c|c|c|c|c|}
\hline Extractant & Target compounds & $\begin{array}{l}\text { Analyzed } \\
\text { species }\end{array}$ & Formula & $\begin{array}{l}\text { Shaking } \\
\text { time }(\mathrm{h})\end{array}$ \\
\hline Magnesium chloride & $\begin{array}{l}\text { Ion-exchangeable } \\
\mathrm{Fe}(\mathrm{II})\end{array}$ & $\begin{array}{l}\text { Adsorbed } \\
\text { ferrous iron }\end{array}$ & $\mathrm{Fe}^{2+}$ & 2 \\
\hline Sodium acetate & Iron carbonates & $\begin{array}{l}\text { Siderite, } \\
\text { Ankerite }\end{array}$ & $\begin{array}{l}\mathrm{FeCO}_{3} \\
\mathrm{Ca}\left(\mathrm{Fe}^{+2}, \mathrm{Mg}^{+2}, \mathrm{Mn}^{+2}\right)\left(\mathrm{CO}_{3}\right)_{2}\end{array}$ & 24 \\
\hline Hydroxylamine hydrochloride & $\begin{array}{l}\text { "Easily reducible" } \\
\text { iron (hydr)oxides }\end{array}$ & $\begin{array}{l}\text { Ferrihydrite, } \\
\text { Lepidicrocite }\end{array}$ & $\begin{array}{l}\mathrm{Fe}_{2}^{3+} \mathrm{O}_{3} \times 0.5\left(\mathrm{H}_{2} \mathrm{O}\right) \\
\gamma-\mathrm{FeOOH}\end{array}$ & 48 \\
\hline Sodium dithionite & "Reducible" oxides & $\begin{array}{l}\text { Goethite, } \\
\text { Hematite, } \\
\text { Akageneite }\end{array}$ & $\begin{array}{l}\alpha-\mathrm{FeOOH} \\
\mathrm{Fe}_{2} \mathrm{O}_{3} \\
\beta-\mathrm{FeOOH}\end{array}$ & 2 \\
\hline Ammonium oxalate & Poorly crystalline & Magnetite & $\mathrm{Fe}_{3} \mathrm{O}_{4}$ & 6 \\
\hline
\end{tabular}

SG-1

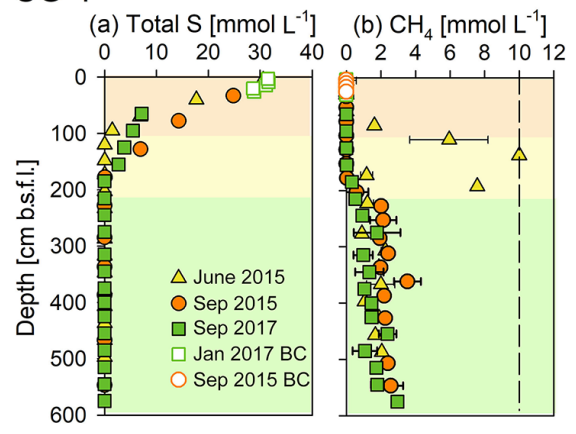

(c) $\delta^{13} C_{D I C}[\%] \quad(d)$

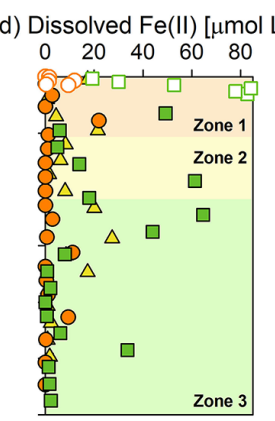

] (e) $\mathrm{H}_{2}\left[\mu \mathrm{mol} \mathrm{L}{ }^{-1}\right]$

(f) Fe [dry wt \%]
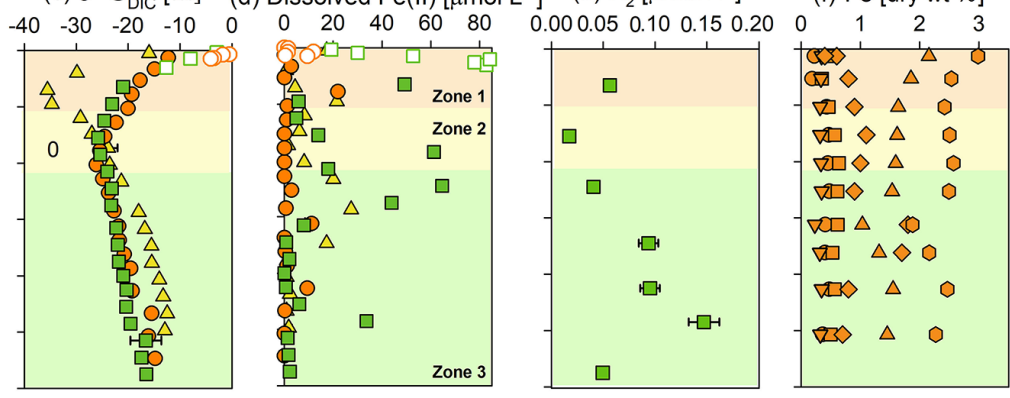

PC-3

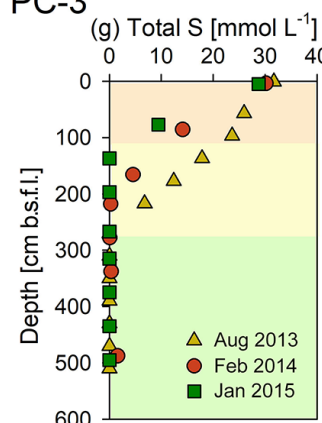

(h) $\mathrm{CH}_{4}\left[\mathrm{mmol} \mathrm{L}^{-1}\right]$

(i) $\delta^{13} \mathrm{C}_{\mathrm{DIC}}[\% \mathrm{\%}]$
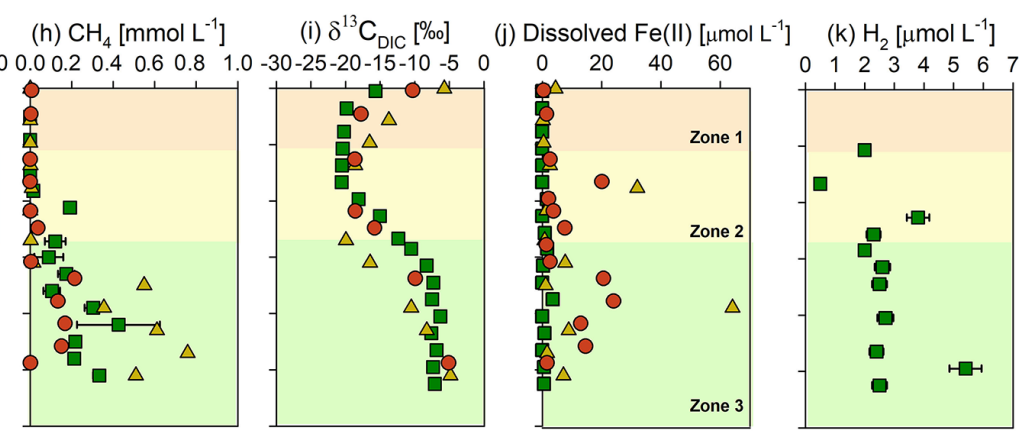

(I) Fe [dry wt \%]

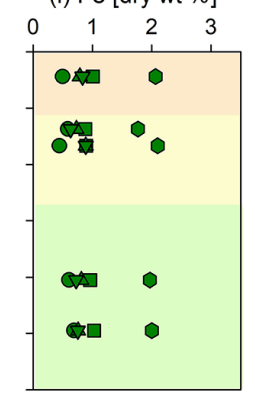

Figure 2. Geochemical porewater profiles of total $\mathrm{S}, \mathrm{CH}_{4}, \delta{ }^{13} \mathrm{C}_{\mathrm{DIC}}$, dissolved $\mathrm{Fe}(\mathrm{II}), \mathrm{H}_{2}$ and extractable Fe fractions from sediment cores collected at the two stations: SG-1 (a-f) and PC-3 (g-l) in the SE Mediterranean. The profiles are divided roughly into three zones according to the dominant processes: upper microbial iron and sulfate reduction, sulfate-methane transition zone (SMTZ), and the methanic zone at the deep part. The dashed line in the $\mathrm{CH}_{4}$ graph at SG-1 station represents the $\mathrm{CH}_{4}$ saturation value in the porewater (Sela-Adler et al., 2015). The following extractable Fe fraction profiles of stations SG-1 (f) and PC-3 (l) are from the September and January 2015 cruise (respectively): $\mathrm{Fe}_{\text {carb }}$ (circle), $\mathrm{Fe}_{\mathrm{ox} 1}$ (square) $\mathrm{Fe}_{\mathrm{ox} 2}$ (triangle), $\mathrm{Fe}_{\mathrm{mag}}$ (inverted triangle), $\mathrm{Fe}_{\text {py }}$ (diamond) (Wurgaft et al., 2019) and total reactive iron (hexagon). The error bars for $\mathrm{CH}_{4}$ are presented where duplicate sediment samples were collected. The error bars for Fe(II), $\delta^{13} \mathrm{C}_{\text {DIC }}$ and $\mathrm{H}_{2}$ are presented where measurements from the same sample were repeated at least twice. The analytical errors were too small to be displayed.

In addition to the dissolved constituents' profiles, reactive iron minerals were extracted from the sediment collected in 2015 , and operationally defined iron mineral fraction profiles from Stations SG-1 and PC-3 were produced (Fig. 2f and 1). In Station SG-1 there appears to be a slight variability in the content of the minerals (Fig. 2f). The Fe $\mathrm{carb}_{\mathrm{s}}$ content in the upper part of the sediment was 0.22 dry wt $\%$, increased to $\sim 0.45$ dry wt $\%$ at $103 \mathrm{~cm}$ depth and then remained constant. The $\mathrm{Fe}_{\mathrm{ox} 1}$ content was 0.49 dry wt $\%$ in the upper part of the sediment, peaked at $203 \mathrm{~cm}$ depth to 0.64 dry wt $\%$ and then decreased to 0.50 dry wt $\%$ at the bottom of the core. The $\mathrm{Fe}_{\mathrm{ox} 2}$ content was 2.15 dry wt $\%$ in the 


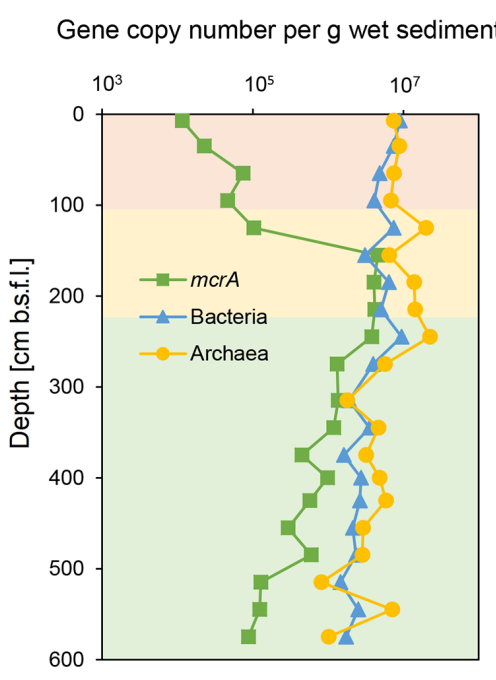

Figure 3. Sedimentary depth profiles of bacterial and archaeal 16S rRNA and mcrA functional genes of station SG-1 from January 2017, divided to three zones (as described in Fig. 2). Triplicates were produced from each sample with error bars smaller than the symbols displayed.

upper part of the sediment, decreased to 1.03 dry wt $\%$ at $312 \mathrm{~cm}$ depth and then increased to 1.55 dry wt $\%$ at $427 \mathrm{~cm}$ depth. $\mathrm{Fe}_{\text {mag }}$ content was 0.34 dry wt $\%$ in the upper part of the sediment, decreased to 0.32 dry wt $\%$ at $153 \mathrm{~cm}$ depth, increased to 0.35 at $253 \mathrm{~cm}$ depth, decreased to 0.23 dry wt \% at $312 \mathrm{~cm}$ depth and increased again to 0.35 dry wt $\%$ at the bottom. A pyrite content profile from Station SG-1 was also produced (Wurgaft et al., 2019) from the September 2015 cruise and shows two peaks: the uppermost of $1.10 \mathrm{wt} \%$ at $153 \mathrm{~cm}$ depth, and the lower one of $1.80 \mathrm{wt} \%$ at $312 \mathrm{~cm}$ depth. The total reactive $\mathrm{Fe}$ (III) oxide profile showed a general decrease from 3.00 dry wt $\%$ at $13 \mathrm{~cm}$ depth to 2.27 dry wt $\%$ at $507 \mathrm{~cm}$ depth, with two minimum peaks of 2.42 dry wt $\%$ at $103 \mathrm{~cm}$ and of 1.88 dry wt $\%$ at $312 \mathrm{~cm}$.

In Station PC-3 there appeared to be smaller changes in the different iron mineral fractions with depth (Fig. 21). The $\mathrm{Fe}_{\text {carb }}$ content in the upper part of the sediment was 0.50 dry wt $\%$ and reached 0.69 dry wt $\%$ in the deep sediment. The $\mathrm{Fe}_{\mathrm{ox} 1}$ content was approximately 1.00 dry wt $\%$ throughout the sediment column. The $\mathrm{Fe}_{\mathrm{ox} 2}$ content was 0.78 drywt $\%$ in the upper part of the sediment, increased to 0.89 dry wt $\%$ at $167 \mathrm{~cm}$ depth and then decreased to 0.76 dry wt $\%$ at $495 \mathrm{~cm}$ depth. $\mathrm{Fe}_{\text {mag }}$ content was 0.83 dry wt $\%$ in the upper part of the sediment, increased to 0.89 dry wt \% at $167 \mathrm{~cm}$ and then decreased again to 0.75 dry wt $\%$ at $495 \mathrm{~cm}$ depth. The total reactive Fe(III) oxide content varied between 2.10 dry wt $\%$ (at $167 \mathrm{~cm}$ depth) and 1.76 dry wt $\%$ (at $137 \mathrm{~cm}$ depth).

\section{Abundance and diversity of bacteria and archaea}

The qPCR of bacterial and archaeal 16S rRNA genes from the SG-1 core (collected on January 2017) revealed an abundance of bacterial genes between 1.46 and $9.45 \times 10^{6}$ copies per gram of wet sediment, while that of archaea was between $8.15 \times 10^{5}$ and $2.25 \times 10^{7}$ copies per gram of wet sediment (Fig. 3). The abundance of bacteria and archaea decreased gradually in the top $95 \mathrm{~cm}$, increased sharply at $125 \mathrm{~cm}$ depth within the SMTZ, remained relatively stable with high abundance at $185-245 \mathrm{~cm}$ (the top layer of the methanic zone) and then decreased. Notably, the abundance of both bacteria and archaea peaked within the methanic zone at $245 \mathrm{~cm}$ in correspondence with the $\mathrm{Fe}$ (II) concentration peak. However, it is not feasible to compare the abundance of archaea and bacteria by this method due to bias caused by the PCR primers used (Buongiorno et al., 2017). The abundance of the $m c r A$ gene (Fig. 3) increased sharply from the surface layer to the SMTZ, peaked at $155 \mathrm{~cm}$ and remained stable at 155 $245 \mathrm{~cm}$, indicative of active anaerobic methane metabolism in the SMTZ and an active methanic zone. Spearman correlation test (Table S2) shows that the abundance of the bacteria and archaea 16S rRNA genes and mcrA genes correlated with $\mathrm{Fe}$ (II) concentration in the methanic zone, where $m c r A$ gene correlated the most significantly $(r=0.5429$, $p$ value $=0.04789$ ) .

Illumina sequencing of the $16 \mathrm{~S}$ rRNA gene revealed diverse bacterial and archaeal communities throughout the SG1 core (Fig. 4). Although no clear plateau was observed on the species rarefaction curve for the current sequencing depth (Fig. S2), Shannon diversity indices reached stable values, indicating that those sequences well covered the diversity of bacterial and archaeal populations in the samples (Fig. S3). Shannon index, based on 16S rRNA gene sequences, shows higher diversity in the top layers of the sediment along with similar values through the core using the bacterial primers, while for sequences using archaeal primers, the values varied in different layers (Table S1). The bacterial sequences were affiliated with the following phyla: Planctomycetes (25.7\%), Chloroflexi (23.2\%), Proteobacteria $(12.9 \%)$, Deinococcus-Thermus $(9.9 \%)$, Acidobacteria (3.5\%), Aminicenantes (3.3\%), Spirochaetes (2.3\%), Deferribacteres $(1.7 \%)$, Elusimicrobia $(1.6 \%)$, Aerophobetes $(1.6 \%)$, Nitrospirae $(1.4 \%)$, Firmicutes $(1.4 \%)$, Actinobacteria $(1.4 \%)$, TM6 (Dependentiae) $(1.2 \%)$, Marinimicrobia (SAR406 clade) $(1.0 \%)$ and other taxa with less than $1 \%$ of the bacterial communities (Fig. 4a). Bathyarchaeota were the predominant archaea in all the sediment layers, based on the high relative abundance of their 16S rRNA gene sequences $(91.0 \%)$. The remaining archaeal phyla comprised Euryarchaeota (3.2\%), Thaumarchaeota (2.4\%), Lokiarchaeota $(1.0 \%)$ and other phyla with less than $1 \%$ of the archaeal communities (Fig. 4b). Spearman correlation analysis (Table S2) revealed that uncultured SBR1093 ( $r=$ $0.6176, p$ value $=0.01859$ ) from bacterial candidate phy- 
(a) Phylum level bacterial diversity

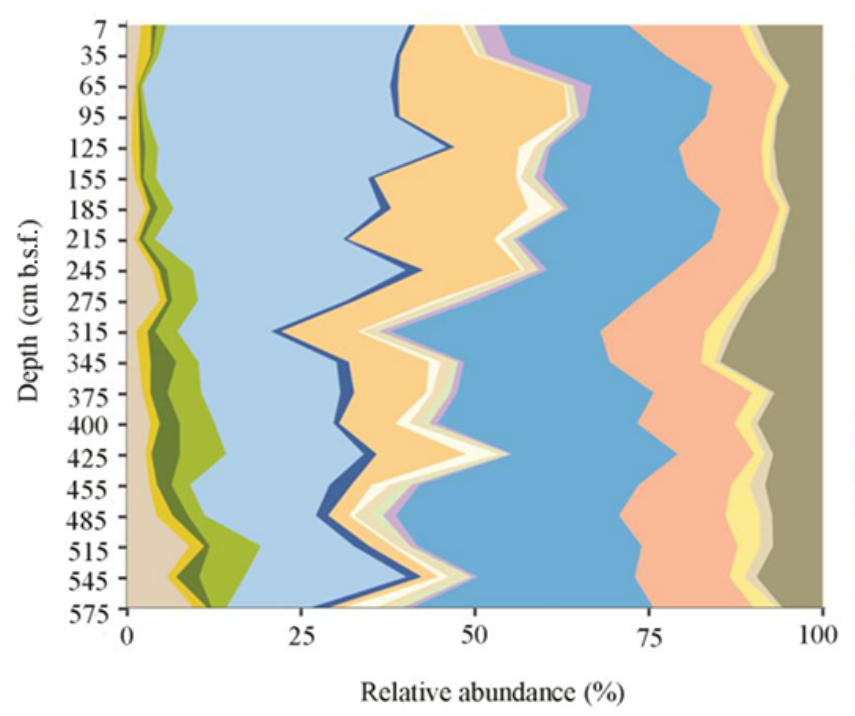

Acidobacteria Actinobacteria Aerophobetes Aminicenantes Chloroflexi Deferribacteres Deinococcus-Thermus Elusimicrobia Firmicutes Marinimicrobia (SAR406 clade) Nitrospirae

Planctomycetes

Proteobacteria Spirochactae TM6 (Dependentiae) Others

(b)

Phylum level archaeal diversity

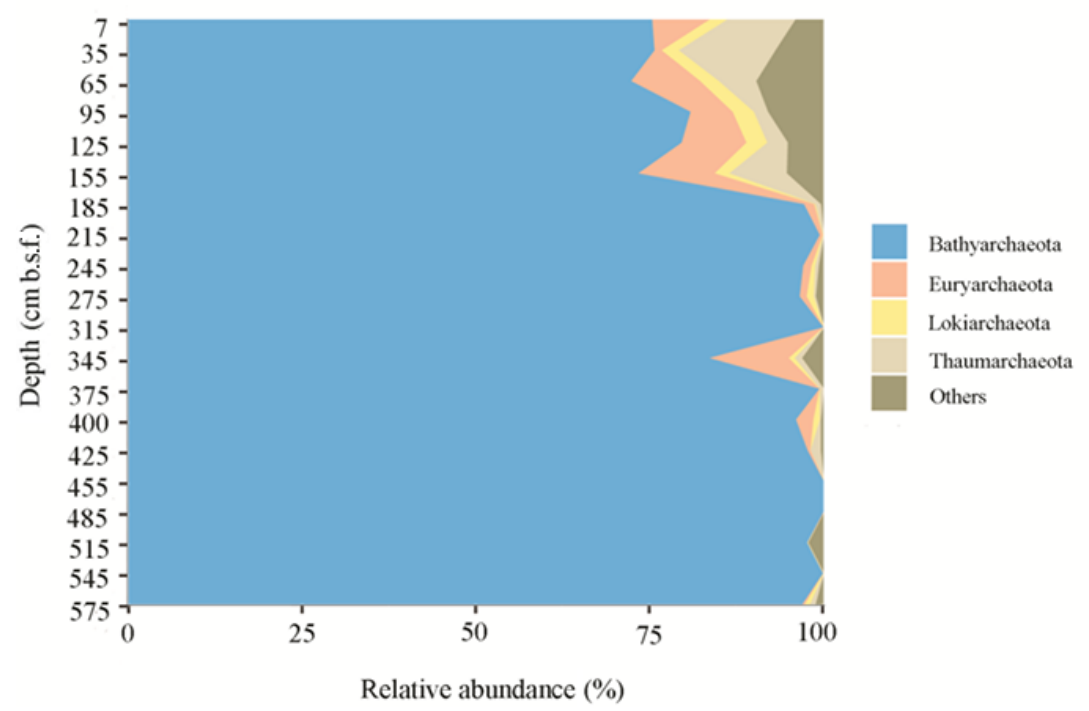

Figure 4. Phylum level classification of bacterial (a) and archaeal (b) diversity in the sediments of Station SG-1 from January 2017.

lum SBR1093, subgroup 26 of Acidobacteria $(r=0.5841$, $p$ value $=0.02828)$, the uncultured bacterium from TK10 class of Chloroflexi phylum $(r=0.5297, p$ value $=0.0544)$ and uncultured Bathyarchaeota sp. (archaea) $(r=0.5516$, $p$ value $=0.04388)$ correlated significantly with $\mathrm{Fe}(\mathrm{II})$ concentration.

\subsection{Incubation experiment}

Sediment from the observed deep iron reduction zone of Station SG-1 from the January 2017 core was used for a simple short-term (couple of weeks) slurry incubation experiment in order to characterize the iron reduction process in the methanic zone. Hematite and magnetite, which were ex- pected to survive the sulfate zone, and were shown to be a source for AOM in lake sediments, were added to the slurries. Indeed, the operationally defined iron mineral fractions profiles (Fig. 2f) confirm that hematite and magnetite were abundant in the methanic zone in this core.

The results of the experiment are shown in Fig. 5. Dissolved $\mathrm{Fe}$ (II) concentrations show a significant increase from $11 \mu \mathrm{mol} \mathrm{L}{ }^{-1}$ to approximately $90 \mu \mathrm{mol} \mathrm{L}^{-1}$ during the first $3 \mathrm{~d}$ in all the experimental bottles, except for the killed bottles, implying that the reduction is microbially mediated. Another observation was that the microorganisms were able to reduce both hematite and magnetite to the same extent. In addition, no difference in the $\mathrm{Fe}(\mathrm{II})$ concentrations between bottles with and without the addition of $\mathrm{H}_{2}$ was observed. 


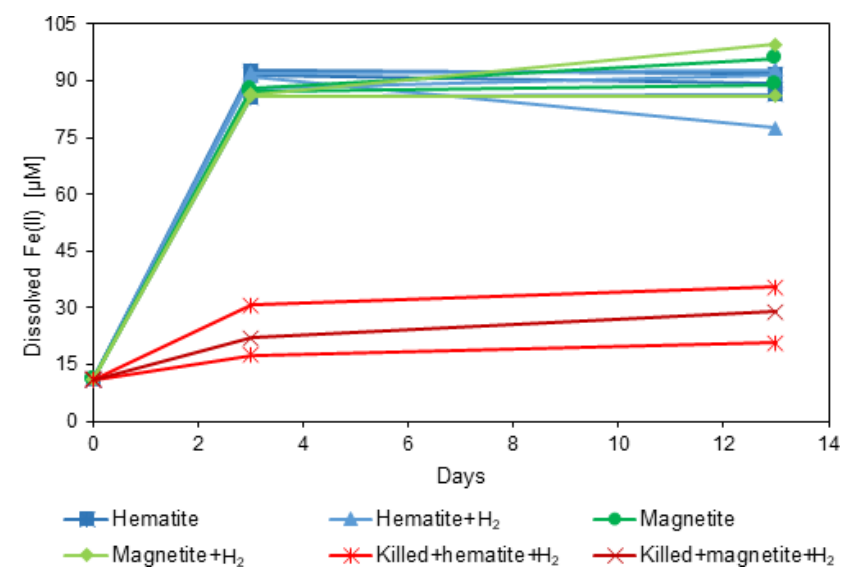

Figure 5. Dissolved Fe(II) results of the sediment slurry incubation experiment. The sediment was collected from Station SG-1 on January 2017 from sediment depth of $265-285 \mathrm{~cm}$. The error bars were smaller than the symbols displayed.

\section{Discussion}

\subsection{General}

This study was performed in the SE Mediterranean (Fig. 1) above the area of a recently discovered gas front (Schattner et al., 2012). The investigated methane was found in the shallow sediments $(\sim 1-5 \mathrm{~m}$ deep) and seems biogenic based on its low $\delta^{13} \mathrm{C}_{\mathrm{CH}_{4}}$ values and high $\mathrm{C}_{1} / \mathrm{C}_{2}$ ratio (Sela-Adler et al., 2015). Station SG-1 is located at the center of the gas front area, while Stations PC-3 and PC-5 are located at the edges, and indeed methane related processes were more intensive at Station SG-1. The source of this gas front is not certain, but it was speculated to be terrestrial organic matter (Schattner et al., 2012). Our results suggest that there are two sources for methane in the shallow sediment: the first is from migration of methane from this gas front area (Wurgaft et al., 2019), and the second is from in situ methane formation, where the relative contribution of each source is currently unknown. In situ methanogenesis in the shallow shelf sediments is evident by the geochemical profiles of $\delta^{13} \mathrm{C}_{\text {DIC }}$ and $\delta^{13} \mathrm{C}_{\mathrm{CH}_{4}}$ (Sela-Adler et al., 2015), by the microbial population abundance profile and by the functional $\mathrm{mcrA}$ gene profile (Figs. 3 and 4, further discussed below). The TOC content in the methanic zone is $\sim 0.8 \%$ at Station SG-1 and $\sim 1 \%$ at Station PC-3 (Sela-Adler et al., 2015), and these levels are known to be able to support in situ methanogenesis (Sivan et al., 2007).

The comparison between the sites show that methane reaches the highest concentrations at Station SG-1 (up to the saturation level; Sela-Adler et al., 2015), specifically in the June 2015 profile (Fig. 2b). This leads to intensive AOM by sulfate at the SMTZ, causing it to occur at shallower depth and to produce lower $\delta^{13} \mathrm{C}_{\mathrm{DIC}}$ values than the other two stations. The relation between the upward fluxes of methane, the SMT depth and the $\delta^{13} \mathrm{C}_{\mathrm{DIC}}$ values fit previous studies (e.g., Sivan et al., 2007). The higher methane concentrations in the June 2015 profile is presumably due to intensive migration of methane from the deeper sediments, and/or more intensive methane production at the exact location of the core collected at that time. The $\mathrm{H}_{2}$ concentrations at Station SG-1 (Fig. 2e) were lower by 2 orders of magnitude than the concentrations at Station PC-3 (Fig. 2k), perhaps due to more intensive hydrogen-consuming processes at Station SG-1 (i.e., sulfate reduction, methanogenesis, iron reduction; Conrad et al., 1986; Lovley, 1991). Dissolved Fe(II) porewater profiles (Fig. $2 \mathrm{~d}$ and $\mathrm{j}$ ) show some variability between the cores within the same station, probably as a result of environmental variations.

Despite the porewater profiles' variability between the stations, they show a resemblance in their trends. All geochemical porewater and iron mineral fraction profiles suggest that the sediments in this area of the SE Mediterranean shelf can be classified into three general depth zones (Fig. 2): zone 1 is the upper part of the sediment, where the classical iron reduction occurs, probably coupled to organic matter oxidation, with sulfate reduction below it; zone 2 is the SMT depth, where methane starts to increase, sulfate is completely depleted, and $\mathrm{Fe}$ (II) (Fig. 2d and j) is either present in low concentrations or absent (probably due to the precipitation of iron-sulfide minerals). In addition, the $\delta^{13} \mathrm{C}_{\text {DIC }}$ values are the lowest in this zone, as expected from the intensive AOM process there, which uses the isotopically light carbon of the methane as a carbon source with small fractionation (Whiticar, 1999; Holler et al., 2009); zone 3 is the methanic zone, where methane concentrations increased to the highest values in all stations, as did the $\delta^{13} \mathrm{C}_{\text {DIC }}$ since the carbon source for the methane comes mainly from $\mathrm{CO}_{2}$, leaving the residual DIC heavier by about $60 \%$ (Whiticar, 1999; Conrad, 2005). In this zone, local maxima of $\mathrm{Fe}(\mathrm{II})$ concentrations in the porewater were found in all cores, indicating reduction of iron oxides. The slurry experiment results show only a slight increase in Fe(II) concentrations in the killed bottles compared to their significant increase in the non-killed bottles, inferring that the iron reduction in zone 3 is microbial (Fig. 5).

\subsection{Potential methanic iron reduction pathways}

This observed intensive iron reduction in the methanic sediments is the first discovered in the SE Mediterranean shelf. The phenomenon of iron reduction in the methanic depth has been observed before in other marine provinces (Jørgensen et al., 2004; März et al., 2008; Slomp et al., 2013; Riedinger et al., 2014; Treude et al., 2014; Oni et al., 2015; Egger et al., 2016). Yet, the type of link to the methane cycle is not well understood. Usually, iron reduction is coupled to oxidation of organic matter (Lovley and Phillips, 1988) and is performed by iron-reducing bacteria, which is probably the case in zone 1 . It is, however, questionable whether this also 
stands for zone 3 and, if not, what process is responsible for the iron reduction at this depth and its relation to methane. The iron reduction in zone 3 can occur potentially via four pathways: (1) oxidation of organic matter arriving from the SMTZ, where it is produced by the microorganisms that live there and benefit from the upward migrating methane, (2) oxidation of the methane itself, (3) $\mathrm{H}_{2}$ oxidation or (4) oxidation of sulfur species through a cryptic cycle.

The oligotrophic nature of the water column in the studied area would suggest that intensive bacterial iron reduction coupled with the oxidation of organic matter in zone 3 is less likely. Nevertheless, we observe high methane concentrations in zone 3 in all three stations, where part of it is from upward migration. This indicates that regardless of the surface water oligotrophic nature, the TOC substrate may be enough to sustain all the microbial activity and to take part in the iron reduction process in the methanic zone. This is possibly due to biomass production in the SMTZ (i.e., the microbial community including anaerobic methanotrophs (ANMEs) and sulfate-reducing bacteria; Boetius et al., 2000) and its rapid use in the methanic zone (so the TOC content remains still low).

The importance of the methane flux as a carbon source that supports the deep microbial community in zone 2 and 3 in the sediments of the SE Mediterranean can be illustrated by comparing the organic carbon flux from the photic zone, with the flux of organic carbon that is oxidized by sulfate in the porewater. Using traps, Moutin and Raimbault (2002) estimated an export flux of $7.4 \pm 6.3 \mathrm{mg} \mathrm{C} \mathrm{m}^{-2} \mathrm{~d}^{-1}$, which leaves the photic zone. However, Wurgaft et al. (2019) estimated that the flux of DIC toward the SMTZ from sulfate reduction is equivalent to $8 \pm 3 \mathrm{mg} \mathrm{C} \mathrm{m}^{-2} \mathrm{~d}^{-1}$. Whereas the difference between the two fluxes is statistically insignificant, it should be noted that the flux of organic material that survives aerobic oxidation in the water column and the upper part of the sediment column, as well as anaerobic oxidation by other electron acceptors with a higher energy yield (Froelich et al., 1979; Emerson et al., 1980), is likely to be substantially smaller than the flux measured by Moutin and Raimbault (2002). Therefore, it is unlikely that export flux from the photic zone constitutes the sole source of carbon to the SMTZ. Wurgaft et al. (2019) suggested that "external" methane originates in deeper portions of the sediments and provides an important source of carbon to the SMTZ in Station SG-1. Such fluxes of "external" methane are common along continental margin sediments (e.g., Milkov and Sassen, 2002; Milkov, 2004; Zhang and Lanoil, 2004; Paull et al., 2008; Fischer et al., 2013). Here, we suggest that this supply of methane leads to intensive sulfate-mediated AOM in the SMTZ, and that this intensive process and biomass may serve as an additional substrate that "fuels" zone 3, activating the iron-oxides.

The recently discovered iron-coupled AOM process (Eq. 3) is the second potential process that can involve ironoxide reduction in the deep methanic zone (Sivan et al., 2011:
Segarra et al., 2013; Slomp et al., 2013; Riedinger et al., 2014; Egger et al., 2014, 2017; Rooze et al., 2016; Bar-Or et al., 2017). $\mathrm{Fe}(\mathrm{IIII})$ as an electron acceptor for AOM provides a greater free energy yield than sulfate (Zehnder and Brock, 1980), and its global importance was emphasized (Sivan et al., 2011, 2014; Segarra et al., 2013). Two of the main environmental conditions for iron-coupled AOM to occur are high dissolved methane concentrations and abundant reducible iron oxides (Riedinger et al., 2005, 2014; Egger et al., 2017). Thus, from our profiles it seems that AOM could be a valid option, considering the high methane concentrations and the high sedimentation rates $\left(0.1 \mathrm{~cm} \mathrm{yr}^{-1}\right.$; Bareket et al., 2016), which allow the iron oxides to survive the sulfidic zone and reach the methanic zone (Riedinger et al., 2005, 2014; Egger et al., 2017). This can also be inferred from Fig. 6, where some association was observed between the dissolved $\mathrm{Fe}(\mathrm{II})$ concentrations and the methane concentrations in zone 3. It seems that at high concentrations of $\mathrm{Fe}(\mathrm{II})$, methane concentrations are low and vice versa. This could be a result of iron-coupled AOM that uses methane to reduce $\mathrm{Fe}(\mathrm{III})$-oxides, releasing dissolved $\mathrm{Fe}(\mathrm{II})$ to the porewater. It can also suggest a type of competitive relationship between methanogenesis and microbial iron reduction, or a microbial population switching from methanogenesis to iron reduction metabolism (e.g., Sivan et al., 2016). It should be noted that our experiment was not designed to test AOM due to its short timescale of a few weeks, and hence another long experiment with the addition of the ${ }^{13} \mathrm{C}$-labeled methane will be needed to shed more light on this association.

The third potential process that can be coupled to iron reduction in the methanic zone is $\mathrm{H}_{2}$ oxidation. $\mathrm{H}_{2}$ is an important intermediate in anoxic aquatic sediments. In this type of environment, it is produced mainly by fermentation of organic matter (Chen et al., 2006) and can be involved in different microbial processes where each process would need a certain amount of $\mathrm{H}_{2}$ in order to occur (Lovley and Goodwin, 1988). The $\mathrm{H}_{2}$ levels at Stations SG-1 and PC-3 (Fig. 2e and $\mathrm{k}$ ) are relatively high in comparison to other marine environments (Lilley et al., 1982; Novelli et al., 1987), suggesting that there is enough $\mathrm{H}_{2}$ to sustain the iron reduction process. The relatively high $\mathrm{H}_{2}$ concentrations at these stations could be explained by the dominance of $\mathrm{H}_{2}$ production processes (i.e., fermentation; Chen et al., 2006) compared to $\mathrm{H}_{2}$-consuming processes (i.e., sulfate reduction, methanogenesis, iron reduction; Conrad et al., 1986; Lovley, 1991). At Station PC-3, the $\mathrm{H}_{2}$ concentrations (Fig. 2k) are constant in zone 3, this suggest that in addition to being produced, $\mathrm{H}_{2}$ is consumed as well. At Station SG-1 (Fig. 2e) there is a maximum peak in zone 3 , indicating that there is either more $\mathrm{H}_{2}$ production or less $\mathrm{H}_{2}$ consumption in this zone compared to zone 2. This is reasonable considering the intensive microbial activity in zone 2 . The decrease in the $\mathrm{H}_{2}$ concentrations below the peak suggests that $\mathrm{H}_{2}$ consuming processes are intensive in this zone. The $\mathrm{H}_{2}$ involvement was tested by injecting $1 \mathrm{~mL}$ of this gas into the experimental bottles in the 

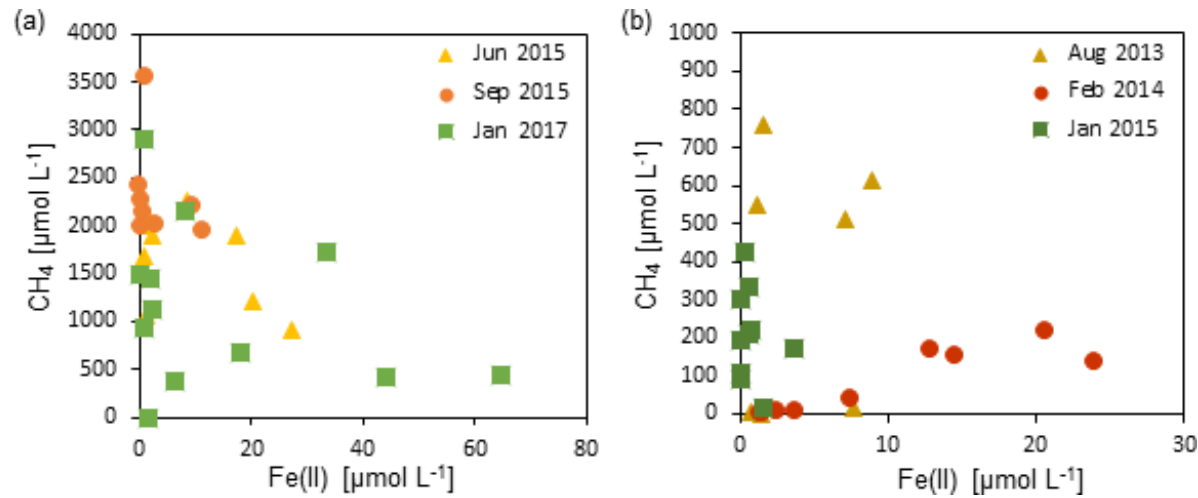

Figure 6. The relationship between dissolved Fe(II) concentrations and methane concentrations in zone 3 of (a) Station SG-1 and (b) Station PC-3. An inverse association is observed between the two species, suggesting a relationship of competition or iron-coupled AOM.

methanic iron reduction process (Fig. 5). We observed that the increase in the $\mathrm{Fe}(\mathrm{II})$ concentration was similar in the bottles with a $\mathrm{H}_{2}$ addition compared to the bottles without $\mathrm{H}_{2}$. This could mean that either there is enough $\mathrm{H}_{2}$ in the sediments as it is, as implied by the $\mathrm{H}_{2}$ porewater profiles, or that at the methanic depth $\mathrm{H}_{2}$ is not involved in the iron reduction process.

The fourth potential way to reduce iron in zone 3 is by an active sulfur cycle. The pyrite profile supports this possibility by showing two peaks, the uppermost in zone 2 of $\sim 1 \mathrm{wt} \%$ and the other in zone 3 of $\sim 2 \mathrm{wt} \%$ at about $300 \mathrm{~cm}$ depth (Fig. 2f). The peak at $300 \mathrm{~cm}$ depth indicates a possible active sulfur cycle, even though sulfate is already undetected at $200 \mathrm{~cm}$. Thus, a possible scenario is that $\mathrm{Fe}(\mathrm{III})$ is reduced by pyrite oxidation (Eq. 3) (Bottrell et al., 2000), which triggers the "cryptic" sulfur cycle, as observed in other marine sediments (Holmkvist et al., 2011; Brunner et al., 2016; Egger et al., 2016). In this cycle, elemental sulfur, and eventually by disproportionation also sulfide and sulfate, is produced. The sulfide reacts with iron-oxide and precipitates as $\mathrm{FeS}$ or as pyrite $\left(\mathrm{FeS}_{2}\right)$ (Holmkvist et al., 2011). The sulfate can inhibit methanogenesis (Mountfort et al., 1980; Mountfort and Asher, 1981), which can result in the enhancement of the iron reduction process due to competition for the substrate with the methanogenesis process. Another indication for an active sulfur cryptic cycle comes from the 16S rRNA sequencing analysis (Fig. 4), which shows that Proteobacteria, a potential sulfur-related bacteria phylum, is one of the most abundant phyla in the sediments. Moreover, the increase in the abundance of Sva0485 order of the Deltaproteobacteria class, a known sulfate reducer (Tan et al., 2019), with depth supports an active sulfur cycle in zone 3 as well.

\subsection{Potential microbial players}

Our data profiles and incubations indicate that the observed iron reduction in the methanic zone of the SE Mediterranean shelf is performed by microbial activity. The microbial re- sults show first that the abundances of the bacteria and archaea (Fig. 4) are typical to oligotrophic marine sediments (e.g., South China Sea that contains $\sim 0.5 \%-1 \%$ TOC, Yu et al., 2018). Second, even though potential bacterial iron reducers, such as Alicyclobacillus, Sulfobacillusin, Desulfotomaculum genera (Firmicutes), Acidiphilium (Alphaproteobacteria), Desulfobulbus, Desulfuromonas, Geobacter, Geothermobacter, Anaeromyxobacter (Deltaproteobacteria) and Shewanella (Gammaproteobacteria) (Weber et al., 2006) comprise less than $0.1 \%$ of bacteria detected in the methanic zone (from $185 \mathrm{~cm}$ and below), it appears that both the microbial abundance and the $\mathrm{Fe}$ (II) concentration peaked in this zone. Cultivation efforts indicated that archaeal methanogens may also play a role in iron reduction within sediments (Sivan et al., 2016). Moreover, the relative abundance of methane-metabolizing archaea was shown to correlate with $\mathrm{Fe}(\mathrm{II})$ concentrations in Helgoland muds from the North Sea, where microbial abundance and the $\mathrm{Fe}(\mathrm{II})$ concentrations peaked in the methanic zone (Oni et al., 2015), similarly to the results found in the SE Mediterranean sediments. It is possible that methane-metabolizing archaea were involved in the iron reduction in the SE Mediterranean sediments, as the highest $m c r A$ gene copies per gram of wet sediment were detected in the SMTZ and at the top of the methanic zone (Fig. 3) where the Fe(II) concentrations are high (Fig. 2d). Methanotrophs, such as ANMEs, were found to be involved in iron-coupled AOM in marine and freshwater cultures (Scheller et al., 2016; McGlynn et al., 2015; Ettwig et al., 2016; Cai et al., 2018). ANMEs were found here with relatively low frequencies (ANME1, below $1 \%$ in most samples, circa $5 \%$ in the $185 \mathrm{~cm}$ layer), and their role in iron reduction within the SE Mediterranean sediments remains to be tested.

In our study, Spearman correlation analysis at Station SG1 (Table S2) revealed that bacterial phyla SBR1093 (candidate phylum), Acidobacteria and Chloroflexi, as well as archaeal phylum Bathyarchaeota, showed significant positive correlation with a $\mathrm{Fe}(\mathrm{II})$ concentration in the methanic 
zone. The candidate phylum SBR1093 was first identified in phosphate-removing activated sludge from a sequencing batch reactor (Bond et al., 1995) and is often detected in a short-chain fatty-acid-rich environment such as wastewater treatment, and marine sediments (Wang et al., 2014). It was thought to be capable of growing autotrophically, but the metabolic capabilities related to iron reduction remain unclear. Strains of Acidobacteria and Chloroflexi phyla were found to be capable of iron reduction (Kawaichi et al., 2013; Kulichevskaya et al., 2014). In addition, members of Acidobacteria were found in iron-coupled AOM enrichment (Beal et al., 2009). The metabolic properties of subgroup 26 from Acidobacteria and TK10 Class of Chloroflexi are still not known. Bathyarchaeota are globally distributed and account for a considerable fraction of the archaeal communities in the marine sediments, particularly in the Mediterranean Pleistocene sapropels (Coolen et al., 2002; Zhou et al., 2018). While Bathyarchaeota have diverse metabolic capabilities (Lloyd et al., 2013; Meng et al., 2014; Evans et al., 2015; He et al., 2016; Yu et al., 2018; Feng et al., 2019), their role in iron reduction warrants further studies, as suggested from their high abundance here. Therefore, iron reduction and methane cycling within the deep methanic zone may be facilitated by an interplay among bacterial and archaeal groups, whose physiology and functions need further investigation.

\section{Conclusions}

Our study used combined geochemical and microbial profiles together with a slurry incubation experiment to show microbial iron reduction in methanic sediments, and the potential microbial population performing this reduction. The Spearman analysis points out several potential microbial players (both bacterial and archaeal) that correlate to the dissolved Fe(II) profiles (e.g., Bathyarchaeota, Acidobacteria and Chloroflexi). Moreover, our study emphasizes that this iron reduction in the methanic zone can occur even in sediments of oligotrophic seas such as the SE Mediterranean. We suggest that the availability of iron minerals for reduction is linked to intensive upward fluxes of methane and high sulfate-AOM rates that may produce available biomass and/or hydrogen, which fuel deeper microbial processes. The deep iron reduction may also be linked to a cryptic sulfur cycle and iron-coupled AOM.

Data availability. Data is available at http://oritsivansgroup. weebly.com/uploads/2/5/5/0/25503858/supplementary_data_ for_vigderovich_et_al_2019.xlsx (last access: 5 August 2019, Vigderovich et al., 2019).

Supplement. The supplement related to this article is available online at: https://doi.org/10.5194/bg-16-3165-2019-supplement.
Author contributions. HV and OS designed research. BH and OS were the PIs of the cruises. HV, EW and LL performed research and analyzed the data. HV, OS, BH, FW, MRB and LL synthesized the data and wrote the paper.

Competing interests. The authors declare that they have no conflict of interest.

Acknowledgements. We thank the captain and crew of the RV Shikmona and RV Bat Galim from the Israel Oceanographic and Limnological Research for all their help during field sampling. Many thanks to Efrat Eliani-Russak for her technical assistance in the lab and to Valeria Boyko for her help with the reactive iron speciation procedure. We also thank all of Orit Sivan's lab members for their help. We would also like to thank the anonymous reviewers for their helpful and constructive comments.

Financial support. This study was supported by the joint grant of Israel Science Foundation and the National Natural Science Foundation of China (ISF-NSFC) (grant numbers 31661143022 (FW) and 2561/16 (OS)). Funding was provided to Hanni Vigderovich by the Mediterranean Sea Research Center of Israel.

Review statement. This paper was edited by Jack Middelburg and reviewed by two anonymous referees.

\section{References}

Adler, M., Eckert, W., and Sivan, O.: Quantifying rates of methanogenesis and methanotrophy in Lake Kinneret sediments (Israel) using pore-water profiles, Limnol. Oceanogr., 56, 1525-1535, https://doi.org/10.4319/lo.2011.56.4.1525, 2011.

Almogi-Labin, A., Herut, B., Sandler, A., and Gelman, F.: Rapid changes along the Israeli Mediterranean coast following the damming of the Nile and their influence on the Israeli inner shelf, Geol. Surv. Israel, Israel, 32 pp., 2009.

Aly Salem, D. M. S., Khaled, A., and El Nemr, A.: Assessment of pesticides and polychlorinated biphenyls (PCBs) in sediments of the Egyptian Mediterranean Coast, Egypt, J. Aquat. Res., 39, 141-152, https://doi.org/10.1016/j.ejar.2013.11.001, 2013.

Antler, G., Turchyn, A. V, Herut, B., and Sivan, O.: A unique isotopic fingerprint of sulfate-driven anaerobic oxidation of methane, Geology, 43, 1-4, https://doi.org/10.1130/G36688.1, 2015.

Astrahan, P., Silverman, J., Gertner, Y., and Herut, B.: Spatial distribution and sources of organic matter and pollutants in the SE Mediterranean Levantine basin deep water sediments, Mar. Pollut. Bull., 116, 521-527, https://doi.org/10.1016/j.marpolbul.2017.01.006, 2017.

Bar-Or, I., Ben-Dov, E., Kushmaro, A., Eckert, W., and Sivan, O.: Methane-related changes in prokaryotes along geochemical profiles in sediments of Lake Kinneret (Israel), Biogeosciences, 12, 2847-2860, https://doi.org/10.5194/bg-12-2847-2015, 2015. 
Bareket, M. M., Bookman, R., Katsman, R., de Stigter, H., and Herut, B.: The role of transport processes of particulate mercury in modifying marine anthropogenic secondary sources, the case of Haifa bay, Israel, Mar. Pollut. Bull., 105, 286-291, https://doi.org/10.1016/j.marpolbul.2016.02.014, 2016.

Bar-Or, I., Elvert, M., Eckert, W., Kushmaro, A., Vigderovich, H., Zhu, Q., Ben-Dov, E., and Sivan, O.: Iron-Coupled Anaerobic Oxidation of Methane Performed by a Mixed Bacterial-Archaeal Community Based on Poorly Reactive Minerals, Environ. Sci. Technol., 51, 12293-12301, https://doi.org/10.1021/acs.est.7b03126, 2017.

Beal, E. J., House, C. H., and Orphan, V. J.: Manganese-and IronDependent Marine Methane Oxidation, Science, 325, 184-187, https://doi.org/10.1126/science.1169984, 2009.

Boetius, A., Ravenschlag, K., Schubert, C. J., Rickert, D., Widdel, F., Gieseke, A., Amann, R., Jùrgensen, B. B., Witte, U., and Pfannkuche, O.: A marine microbial consortium apparently mediating anaerobic oxidation of methane, Nature, 407, 623-626, 2000.

Bond, D. R. and Lovley, D. R.: Reduction of Fe (III) oxide by methanogens in the presence and absence of extracellular quinones, Environ. Microbiol., 4, 115-124, https://doi.org/10.1046/j.1462-2920.2002.00279.x, 2002.

Bond, P. L., Hugenholtz, P., Keller, J., and Blackall, L. L.: Bacterial Community Structures of Phosphate-Removing and NonPhosphate-Removing Activated Sludges from Sequencing Batch Reactors, Appl. Environ. Microbial., 61, 1910-1916, 1995.

Bottrell, S. H., Parkes, R. J., Cragg, B. A., and Raiswell, R.: Isotopic evidence for anoxic pyrite oxidation and stimulation of bacterial sulphate reduction in marine sediments, J. Geol. Soc. London, 157, 711-714, https://doi.org/10.1144/jgs.157.4.711, 2000.

Bray, M. S., Jieying, W., Reed, B. C., Kretz, C. B., Belli, K. M., Simister, R. L., Henny, C., Stewart, F. J., DiChristina, T. J., Brandes, J. A., Fowle, D. A., Crowe, S. A., and Glass, J. B.: Shifting microbial communities sustain multi-year iron reduction and methanogenesis in ferruginous sediment incubations, Geobiology, 15, 1-12, https://doi.org/10.1101/087783, 2018.

Brunner, B., Arnold, G. L., Røy, H., Müller, I. A., and Jørgensen, B. B.: Off Limits?: Sulfate below the Sulfate-Methane Transition, Front. Earth Sci., 4, 1-16, https://doi.org/10.3389/feart.2016.00075, 2016.

Buongiorno, J., Turner, S., Webster, G., Asai, M., Shumaker, A. K., Roy, T., Weightman, A., Schippers, A., and Lloyd, K. G.: Interlaboratory quantification of Bacteria and Archaea in deeply buried sediments of the Baltic Sea, IODP Expedition 347, FEMS Microbiol. Ecol., 93, 1-16, https://doi.org/10.1093/femsec/fix007, 2017.

Cai, C., Leu, A. O., Jianhua, G. X., Yuexing, G., Zhao, F. J., and Tyson, G. W.: A methanotrophic archaeon couples anaerobic oxidation of methane to Fe (III) reduction, ISME J., 8, 1929-1939, https://doi.org/10.1038/s41396-018-0109-x, 2018.

Canfield, D. E.: Reactive iron in marine sediments, Geochim. Cosmochim. Ac., 53, 619-632, https://doi.org/10.1016/00167037(89)90005-7, 1989.

Caporaso, J. G., Kuczynski, J., Stombaugh, J., Bittinger, K., Bushman, F. D., Costello, E. K., Fierer, N., Peña, A. G., Goodrich, J. K., Gordon, J. I., Huttley, G. A., Kelley, S. T., Knights, D., Koenig, J. E., Ley, R. E., Lozupone, C. A., McDonald, D., Muegge, B. D., Pirrung, M., Reeder, J., Sevinsky, J. R.,
Turnbaugh, P. J., Walters, W. A., Widmann, J., Yatsunenko, T., Zaneveld, J., and Knight, R.: QIIME allows analysis of highthroughput com- munity sequencing data, Nat. Methods, 7, 335336, https://doi.org/10.1038/nmeth.f.303, 2010.

Chen, W. H., Chen, S. Y., Kumar Khanal, S., and Sung, S.: Kinetic study of biological hydrogen production by anaerobic fermentation, Int. J. Hydrogen Energ., 31, 2170-2178, https://doi.org/10.4304/jcp.6.4.740-746, 2006.

Cline, J. D.: Spectrophotometric determination of hydrogen sulfide in natural waters, Limnol. Oceanogr., 14, 454-458, https://doi.org/10.4319/lo.1969.14.3.0454, 1969.

Conrad, R.: Contribution of hydrogen to methane production and control of hydrogen concentrations in methanogenic soils and sediments, FEMS Microbiol. Ecol., 28, 193-202, 1999.

Conrad, R.: Quantification of methanogenic pathways using stable carbon isotopic signatures?: a review and a proposal, Org. Geochem., 36, 739-752, https://doi.org/10.1016/j.orggeochem.2004.09.006, 2005.

Conrad, R., Schink, B., and Phelps, T. J.: Thermodynamics of $\mathrm{H}_{2}$-consuming and $\mathrm{H}_{2}$-producing metabolic reactions in diverse methanogenic environments under in situ conditions, FEMS Microbiol. Ecol., 38, 353-360, 1986.

Coolen, M. J. L., Cypionka, H., Sass, A. M., Sass, H., and Overmann, J.: Ongoing modification of Mediterranean pleistocene sapropels mediated by prokaryotes, Science, 296, 2407-2411, https://doi.org/10.1126/science.1071893, 2002.

Crowe, S. A., Katsev, S., Leslie, K., Sturm, A., Magen, C., Nomosatryo, S., Pack, M. A., Kessler, J. D., Reeburgh, W. S., Robert S, J. A., Gonzalez, L., Douglas Haffner, G., Mucci, A., Sundby, B., and Fowle, D.: The methane cycle in ferruginous Lake Matano, Geobiology, 9, 61-78, https://doi.org/10.1111/j.1472-4669.2010.00257.x, 2011.

Egger, M., Rasigraf, O., Sapart, C. J., Jilbert, T., Jetten, M. S. M., Röckmann, T., Van Der Veen, C., Bânda, N., Kartal, B., Ettwig, K. F., and Slomp, C. P.: Iron-mediated anaerobic oxidation of methane in brackish coastal sediments, Environ. Sci. Technol., 49, 277-283, https://doi.org/10.1021/es503663z, 2014.

Egger, M., Kraal, P., Jilbert, T., Sulu-Gambari, F., Sapart, C. J., Röckmann, T., and Slomp, C. P.: Anaerobic oxidation of methane alters sediment records of sulfur, iron and phosphorus in the Black Sea, Biogeosciences, 13, 5333-5355, https://doi.org/10.5194/bg-13-5333-2016, 2016.

Egger, M., Hagens, M., Sapart, C. J., Dijkstra, N., van Helmond, N. A. G. M., Mogollón, J. M., Risgaard-Petersen, N., van der Veen, C., Kasten, S., Riedinger, N., Böttcher, M. E., Röckmann, T., Jørgensen, B. B., and Slomp, C. P.: Iron oxide reduction in methanerich deep Baltic Sea sediments, Geochim. Cosmochim. Ac., 207, 256-276, https://doi.org/10.1016/j.gca.2017.03.019, 2017.

Emerson, S., Jahnke, R., Bender, M., Froelich, P., and Klinkhammer, G.: Early diagenesis in sediments from the eastern equatorial pacific, I. pore water nutrient and carbonate results, Earth Planet. Sc. Lett., 49, https://doi.org/10.1016/0012821X(80)90150-8, 1980.

Ettwig, K. F., Zhu, B., Speth, D., Keltjens, J. T., Jetten, M. S. M., and Kartal, B.: Archaea catalyze iron-dependent anaerobic oxidation of methane, P. Natl. Acad. Sci. USA, 113, 12792-12796, https://doi.org/10.1073/pnas.1609534113, 2016.

Evans, P. N., Parks, D. H., Chadwick, G. L., Robbins, S. J., Orphan, V. J., Golding, S. D., and Tyson, G. W.: Methane 
metabolism in the archaeal phylum Bathyarchaeota revealed by genome-centric metagenomics, Science, 350, 434-438, https://doi.org/10.1126/science.aac7745, 2015.

Feng, X., Wang, Y., Zubin, R., and Wang, F.: Core Metabolic Features and Hot Origin of Bathyarchaeota, Engineering, 5, 498504, https://doi.org/10.1016/j.eng.2019.01.011, 2019.

Fischer, D., Mogollón, J. M., Strasser, M., Pape, T., Bohrmann, G., Fekete, N., Spiess, V., and Kasten, S.: Subduction zone earthquake as potential trigger of submarine hydrocarbon seepage, Nat. Geosci., 6, 1-5, https://doi.org/10.1038/ngeo1886, 2013.

Froelich, P. N., Klinkhammer, G. P., Bender, M. L., Luedtke, N. A., Heath, G. R., Cullen, D., Dauphin, P., Hammond, D., Hartman, B., and Maynard, V.: Early oxidation of organic matter in pelagic sediments of the eastern equatorial Atlantic: Suboxic diagenesis, Geochim. Cosmochim. Ac., 43, 1075-1090, https://doi.org/10.1016/0016-7037(79)90095-4, 1979.

He, Y., Li, M., Perumal, V., Feng, X., Fang, J., Xie, J., Sievert, S. M., and Wang, F.: Genomic and enzymatic evidence for acetogenesis among multiple lineages of the archaeal phylum Bathyarchaeota widespread in marine sediments, Nat. Microbiol., 1, 16035, https://doi.org/10.1038/nmicrobiol.2016.35, 2016.

Herut, B., Almogi-Labin, A., Jannink, N., and Gertman, I.: The seasonal dynamics of nutrient and chlorophyll a concentrations on the SE Mediterranean shelf-slope, Oceanol. Acta, 23, 771-782, https://doi.org/10.1016/S0399-1784(00)01118-X, 2000.

Hinrichs, K., Hayes, J. M., and Sylva, S. P.: Methane-consuming archaebacteria in marine sediments, Nature, 398, 802-805, 1999.

Hoehler, T. M., Alperin, M. J., Albert, D. B., and Martens, C. S.: Field and laboratory studies of methane oxidation in an anoxic marine sediment: evidence for a methanogen-sulfate reducer consortium, Global Biogeochem. Cy., 8, 451-463, https://doi.org/10.1029/94GB01800, 1994.

Holler, T., Wegener, G., Knittel, K., Boetius, A., Brunner, B., Kuypers, M. M. M., and Widdel, F.: Substantial ${ }^{13} \mathrm{C} /{ }^{12} \mathrm{C}$ and $\mathrm{D} / \mathrm{H}$ fractionation during anaerobic oxidation of methane by marine consortia enriched in vitro, Environ. Microbiol. Reports., 1, 370-376, https://doi.org/10.1111/j.1758-2229.2009.00074.x, 2009.

Holmkvist, L., Ferdelman, T. G., and Jørgensen, B. B.: A cryptic sulfur cycle driven by iron in the methane zone of marine sediment (Aarhus Bay, Denmark), Geochim. Cosmochim. Ac., 75, 3581-3599, https://doi.org/10.1016/j.gca.2011.03.033, 2011.

Iversen, N. and Jørgensen, B. B.: Anaerobic methane oxidation rates at the sulfate-methane transition in marine sediments from Kattegat and Skagerrak (Denmark), Limnol. Oceanogr., 5, 944-955, 1985.

Jørgensen, B. B., Böttcher, M. E., Lüschen, H., Neretin, L. N., and Volkov, I. I.: Anaerobic methane oxidation and a deep $\mathrm{H}_{2} \mathrm{~S}$ sink generate isotopically heavy sulfides in Black Sea sediments, Geochim. Cosmochim. Ac., 68, 2095-2118, https://doi.org/10.1016/j.gca.2003.07.017, 2004.

Kawaichi, S., Ito, N., Kamikawa, R., Sugawara, T., Yoshida, T., and Sako, Y.: Ardenticatena maritima gen. nov., sp. nov., a ferric ironand nitrate-reducing bacterium of the phylum "Chloroflexi" isolated from an iron-rich coastal hydrothermal field, and description of Ardenticatenia classis nov, Int. J. Syst. Evol. Microbiol., 63, 2992-3002, https://doi.org/10.1099/ijs.0.046532-0, 2013.

Knittel, K. and Boetius, A.: Anaerobic Oxidation of Methane?: Progress with an Unknown
Process, Annu. Rev. Microbiol., 63, 311-334, https://doi.org/10.1146/annurev.micro.61.080706.093130, 2009.

Kress, N. and Herut, B.: Spatial and seasonal evolution of dissolved oxygen and nutrients in the Southern Levantine Basin (Eastern Mediterranean Sea): chemical characterization of the water masses and inferences on the N:P ratios, Deep-Sea Res. Pt. I, 48, 2347-2372, https://doi.org/10.1016/S0967-0637(01)00022X, 2001.

Kulichevskaya, I. S., Suzina, N. E., Rijpstra, W. I. C., Dedysh, S. N., and Damste, J. S. S.: a facultative anaerobe capable of dissimilatory iron reduction from subdivision 3 of the Acidobacteria, Int. J. Syst. Evol. Microbiol., 64, 2857-2864, https://doi.org/10.1099/ijs.0.066175-0, 2014.

Li, Y., Yu, S., Strong, J., and Wang, H.: Are the biogeochemical cycles of carbon, nitrogen, sulfur, and phosphorus driven by the "Fe III-Fe II redox wheel" in dynamic redox environments?, J. soils sediments, 12, 683-693, https://doi.org/10.1007/s11368012-0507-z, 2012.

Lilley, M. D., Baross, J. A., and Gordon, L. I.: Dissolved hydrogen and methane in Saanich Inlet, British Columbia, DeepSea Res. Pt. A, 29, 1471-1484, https://doi.org/10.1016/01980149(82)90037-1, 1982.

Liu, D., Dong Hailiang, H., Bishop, M. E., Wang, H., Agrawal, A., Tritschler, S., Eberl, D. D., and Xie, S.: Reduction of structural $\mathrm{Fe}(\mathrm{III})$ in nontronite by methanogen Methanosarcina barkeri, Geochim. Cosmochim. Ac., 75, 10571071, https://doi.org/10.1016/j.gca.2010.11.009, 2011.

Lloyd, K. G., Schreiber, L., Petersen, D. G., Kjeldsen, K. U., Lever, M. A., Steen, A. D., Stepanauskas, R., Richter, M., Kleindienst, S., Lenk, S., Schramm, A., and Jørgensen, B. B.: Predominant archaea in marine sediments degrade detrital proteins, Nature, 496, 215-218, https://doi.org/10.1038/nature12033, 2013.

Lovley, D. R.: Dissimilatory Fe(III) and Mn(IV) reduction, Microbiol. Rev., 55, 259-287, 1991.

Lovley, D.: Microbial $\mathrm{Fe}(\mathrm{III})$ reduction in subsurface environments, FEMS Microbiol. Rev., 20, 305-313, https://doi.org/10.1111/j.1574-6976.1997.tb00316.x/full, 1997.

Lovley, D. R. and Goodwin, S.: Hydrogen concentrations as an indicator of the predominant terminal electron-accepting reactions in aquatic sediments, Geochim. Cosmochim. Ac., 52, 2993-3003, https://doi.org/10.1016/0016-7037(88)90163-9, 1988.

Lovley, D. R. and Phillips, E. J. P.: Organic matter mineralization with reduction of ferric iron in anaerobic sediments, Appl. Environ. Microbiol., 51, 683-689, https://doi.org/10.1080/01490458709385975, 1986.

Lovley, D. R. and Phillips, E. J.: Novel mode of microbial energy metabolism: organic carbon oxidation coupled to dissimilatory reduction of iron or manganese, Appl. Environ. Microbiol., 54, 1472-1480, https://doi.org/10.1103/PhysRevLett.50.1998, 1988. Lovley, D. R., Stolz, J. F., Nord, G. L., and Phillips, E. J. P.: Anaerobic production of magnetite by a dissimilatory iron-reducing microorganism, Nature, 330, 252-254, https://doi.org/10.1038/330252a0, 1987.

Lovley, D. R., Coates, J. D., BluntHarris, E. L., Phillips, E. J. P., and Woodward, J. C.: Humic substances as electron acceptors for microbial respiration, Nature, 382, 445-448, https://doi.org/10.1038/382445a0, 1996. 
März, C., Hoffmann, J., Bleil, U., de Lange, G. J., and Kasten, S.: Diagenetic changes of magnetic and geochemical signals by anaerobic methane oxidation in sediments of the Zambezi deep-sea fan (SW Indian Ocean), Mar. Geol., 255, 118-130, https://doi.org/10.1016/j.margeo.2008.05.013, 2008.

März, C., Riedinger, N., Sena, C., and Kasten, S.: Phosphorus dynamics around the sulphate-methane transition in continental margin sediments?: Authigenic apatite and Fe (II) phosphates, Mar. Geol., 404, 84-96, https://doi.org/10.1016/j.margeo.2018.07.010, 2018.

McGlynn, S. E., Chadwick, G. L., Kempes, C. P., and Orphan, V. J.: Single cell activity reveals direct electron transfer in methanotrophic consortia, Nature, 526, 531-535, https://doi.org/10.1038/nature15512, 2015.

Meng, J., Xu, J., Qin, D., He, Y., Xiao, X., and Wang, F.: Genetic and functional properties of uncultivated MCG archaea assessed by metagenome and gene expression analyses, ISME J., 8, 650659, https://doi.org/10.1038/ismej.2013.174, 2014.

Milkov, A. V: Global estimates of hydrate-bound gas in marine sediments?: how much is really out there?, Earth-Science Rev., 66, 183-197, https://doi.org/10.1016/j.earscirev.2003.11.002, 2004.

Milkov, A. V. and Sassen, R.: Economic geology of offshore gas hydrate accumulations and provinces, Mar. Pet. Geol., 19, 1-11, https://doi.org/10.1016/S0264-8172(01)00047-2, 2002.

Mountfort, D. O. and Asher, R. A.: Role of Sulfate Reduction Versus Methanogenesis in Terminal Carbon Flow in Polluted Intertidal Sediment of Waimea Inlet, Nelson, New Zealand, Appl. Environ. Microbiol., 42, 252-258, 1981.

Mountfort, D. O., Asher, R. A., Mays, E. L., and Tiedje, J. M.: Carbon and electron flow in mud and sandflat intertidal sediments at delaware inlet, nelson, new zealand., Appl. Environ. Microbiol., 39, 686-94, 1980.

Moutin, T. and Raimbault, P.: Primary production, carbon export and nutrients availability in western and eastern Mediterranean Sea in early summer 1996 (MINOS cruise), J. Mar. Syst., 34, 273-288, https://doi.org/10.1016/S0924-7963(02)00062-3, 2002.

Neiwöhner, C., Hensen, C., Kasten, S., Zabel, M., and Schulz, H. D.: Deep sulfate reduction completely mediated by anaerobic methane oxidation in sediments of the upwelling area off Namibia, Geochim. Cosmochim. Ac., 62, 455-464, 1998.

Nir, Y.: Recent sediments of the Israel Mediterranean continental shelf and slope, PhD thesis, University of Gothenburg, Sweden, 221 pp., 1984.

Niu, M., Fan, X., Zhuang, G., Liang, Q., and Wang, F.: Methane-metabolizing microbial communities in sediments of the Haima cold seep area, northwest slope of the South China Sea, FEMS Microbiol. Ecol., 93, 1-13, https://doi.org/10.1093/femsec/fix101, 2017.

Norði, K. Á., Thamdrup, B., and Schubert, C. J.: Anaerobic oxidation of methane in an iron-rich Danish freshwater lake sediment, Limnol. Oceanogr., 58, 546-554, https://doi.org/10.4319/1o.2013.58.2.0546, 2013.

Novelli, P. C., Scranton, M. I., and Michener, R. H.: Hydrogen Distributions in Marine Sediments Hydrogen distributions, Limnol. Oceanogr., 32, 565-576, https://doi.org/10.4319/lo.1987.32.3.0565, 1987.

Nüsslein, B., Eckert, W., and Conrad, R.: Stable isotope biogeochemistry of methane formation in profundal sediments of Lake Kinneret (Israel), Limnol. Oceanogr., 48, 1439-1446, https://doi.org/10.4319/lo.2003.48.4.1439, 2003.

Oni, O., Miyatake, T., Kasten, S., Richter-Heitmann, T., Fischer, D., Wagenknecht, Laura Kulkarni, A., Blumers, M., Shylin, S. I., Ksenofontov, Vadim Costa, B. F. O., Klingelhöfer, G., and Friedrich, M. W.: Distinct microbial populations are tightly linked to the profile of dissolved iron in the methanic sediments of the Helgoland mud area, North Sea, Front. Microbiol., 6, 115, https://doi.org/10.3389/fmicb.2015.00365, 2015.

Orphan, V. J., House, C. H., and Hinrichs, K.: MethaneConsuming Archaea Revealed by Directly Coupled Isotopic and Phylogenetic Analysis, Science, 293, 484-488, https://doi.org/10.1126/science.1061338, 2001.

Paull, C. K., Normark, W. R., Ussler, W., Caress, D. W., and Keaten, R.: Association among active seafloor deformation, mound formation, and gas hydrate growth and accumulation within the seafloor of the Santa Monica Basin, offshore California, Mar. Geol., 250, 258-275, https://doi.org/10.1016/j.margeo.2008.01.011, 2008.

Poulton, S. W. and Canfield, D. E.: Development of a sequential extraction procedure for iron: Implications for iron partitioning in continentally derived particulates, Chem. Geol., 214, 209-221, https://doi.org/10.1016/j.chemgeo.2004.09.003, 2005.

Poulton, S. W., Krom, M. D., and Raiswell, R.: A revised scheme for the reactivity of iron (oxyhydr)oxide minerals towards dissolved sulfide, Geochim. Cosmochim. Ac., 68, 3703-3715, https://doi.org/10.1016/j.gca.2004.03.012, 2004.

Riedinger, N., Pfeifer, K., Kasten, S., Garming, J. F. L., Vogt, C., and Hensen, C.: Diagenetic alterations of magnetic signals by anaerobic oxidation of methane related to a change in sedimentation rate, Geochim. Cosmochim. Ac., 69, 4117-4126, https://doi.org/10.1016/j.gca.2005.02.004, 2005.

Riedinger, N., Formolo, M. J., Lyons, T. W., Henkel, S., Beck, A., and Kasten, S.: An inorganic geochemical argument for coupled anaerobic oxidation of methane and iron reduction in marine sediments, Geobiology, 12, 172-181, 2014.

Riedinger, N., Brunner, B., Krastel, S., Arnold, G. L., Wehrmann, L. M., Formolo, M. J., Beck, A., Bates, S. M., Henkel, S., Kasten, S., and Lyons, T. W.: Sulfur Cycling in an Iron Oxide-Dominated, Dynamic Marine Depositional System?: The Argentine Continental Margin, Front. Earth Sci., 5, 33 pp., https://doi.org/10.3389/feart.2017.00033, 2017.

Roden, E. E.: Fe(III) Oxide Reactivity Toward Biological versus Chemical Reduction, Environ. Sci. Technol., 37, 1319-1324, https://doi.org/10.1021/es026038o, 2003.

Roden, E. E.: Geochemical and microbiological controls on dissimilatory iron reduction, C. R. Geo. Sci., 338, 456-467, https://doi.org/10.1016/j.crte.2006.04.009, 2006.

Roden, E. E. and Wetzel, R. G.: Organic carbon oxidation and suppression of methane production by microbial $\mathrm{Fe}(\mathrm{III})$ oxide reduction in vegetated and unvegetated freshwater wetland sediments, Limnol. Oceanogr., 41. 1733-1748, https://doi.org/10.4319/lo.1996.41.8.1733, 1996.

Roden, E. E. and Wetzel, R. G.: Kinetics of microbial Fe(III) oxide reduction in freshwater wetland sediments, Limnol. Ocean., 47. 198-211, https://doi.org/10.4319/1o.2002.47.1.0198, 2002.

Rooze, J., Egger, M., Tsandev, I., and Slomp, C. P.: Iron-dependent anaerobic oxidation of methane in coastal surface sediments: po- 
tential controls and impact, Limnol. Oceanogr., 61, S267-S282, https://doi.org/10.1002/lno.10275, 2016.

Rotaru, B. A. and Thamdrup, B.: A new diet for methane oxidizers, Biogeochemistry, 351, 658-660, https://doi.org/10.1126/science.aaf0741, 2016.

Sandler, A. and Herut, B.: Composition of clays along the continental shelf off Israel: Contribution of the Nile versus local sources, Mar. Geol., 167, 339-354, https://doi.org/10.1016/S00253227(00)00021-9, 2000.

Schattner, U., Lazar, M., Harari, D., and Waldmann, N.: Active gas migration systems offshore northern Israel, first evidence from seafloor and subsurface data, Cont. Shelf Res., 48, 167-172, https://doi.org/10.1016/j.csr.2012.08.003, 2012.

Scheller, S., Yu, H., Chadwick, G. L., McGlynn, S. E., and Orphan, V. J.: Artificial electron acceptors decouple archaeal methane oxidation from sulfate reduction, Science, 351, 1754-1756, https://doi.org/10.1126/science.aad7154, 2016.

Segarra, K. E. A., Comerford, C., Slaughter, J., and Joye, S. B.: Impact of electron acceptor availability on the anaerobic oxidation of methane in coastal freshwater and brackish wetland sediments, Geochim. Cosmochim. Ac., 115, 15-30, https://doi.org/10.1016/j.gca.2013.03.029, 2013.

Sela-Adler, M., Herut, B., Bar-Or, I., Antler, G., Eliani-Russak, E., Levy, E., Makovsky, Y., and Sivan, O.: Geochemical evidence for biogenic methane production and consumption in the shallow sediments of the SE Mediterranean shelf (Israel), Cont. Shelf Res., 101, 117-124, https://doi.org/10.1016/j.csr.2015.04.001, 2015.

Sivan, O., Schrag, D. P., and Murray, R. W.: Rates of methanogenesis and methanotrophy in deep-sea sediments, Geobiology, 5, 141-151, https://doi.org/10.1111/j.1472-4669.2007.00098.x, 2007.

Sivan, O., Adler, M., Pearson, A., Gelman, F., Bar-Or, I., John, S. G., and Eckert, W.: Geochemical evidence for iron-mediated anaerobic oxidation of methane, Limnol. Oceanogr., 56, 15361544, https://doi.org/10.4319/lo.2011.56.4.1536, 2011.

Sivan, O., Antler, G., Turchyn, A. V., Marlow, J. J., and Orphan, V. J.: Iron oxides stimulate sulfate-driven anaerobic methane oxidation in seeps, P. Natl. Acad. Sci. USA, 111, E4139-E4147, https://doi.org/10.1073/pnas.1412269111, 2014.

Sivan, O., Shusta, S., and Valentine, D. L.: Methanogens rapidly transition from methane production to iron reduction, Geobiology, 14, 190-203, https://doi.org/10.1111/gbi.12172, 2016.

Slomp, C. P., Mort, H. P., Jilbert, T., Reed, D. C., Gustafsson, B. G., and Wolthers, M.: Coupled Dynamics of Iron and Phosphorus in Sediments of an Oligotrophic Coastal Basin and the Impact of Anaerobic Oxidation of Methane, Plos One, 8, e62386, https://doi.org/10.1371/journal.pone.0062386, 2013.

Song, Z., Wang, F., Zhi, X., Chen, J., Zhou, E., Liang, F., Xiao, X., Tang, S., Jiang, H., Zhang, C. L., Dong, H., and Li, W.: Bacterial and archaeal diversities in Yunnan and Tibetan hot springs, China, Environ. Microbiol., 15, 1160-1175, https://doi.org/10.1111/1462-2920.12025, 2013.

Stookey, L. L.: Ferrozine-a new spectrophotometric reagent for iron, Anal. Chem., 42, 779-781, https://doi.org/10.1021/ac60289a016, 1970.

Tan, S., Liu, J., Fang, Y., Hedlund, B. P., Lian, Z., Li, L. H. J., Li, L. H. W., Dong, H. J. H., and Shu, W.: Insights into ecological role of a new deltaproteobacterial order Candidatus Acidulodesul- fobacterales by metagenomics and metatranscriptomics, ISME J., 13, 2044-2057, https://doi.org/10.1038/s41396-019-0415-y, 2019.

Treude, T., Krause, S., Maltby, J., Dale, A. W., Coffin, R., and Hamdan, L. J.: Sulfate reduction and methane oxidation activity below the sulfate-methane transition zone in Alaskan Beaufort Sea continental margin sediments: Implications for deep sulfur cycling, Geochim. Cosmochim. Ac., 144, 217-237, https://doi.org/10.1016/j.gca.2014.08.018, 2014.

Valentine, D. L.: Biogeochemistry and microbial ecology of methane oxidation in anoxic environments: A review, Antonie van Leeuwenhoek, Int. J. Gen. Mol. Microbiol., 81, 271-282, https://doi.org/10.1023/A:1020587206351, 2002.

Vigderovich, H., Liang, L., Herut, B., Wang, F., Wurgaft, E., RubinBlum, M., and Sivan, O.: Supplementary data, available at: http://oritsivansgroup.weebly.com/uploads/2/5/5/0/25503858/ supplementary_data_for_vigderovich_et_al_2019.xlsx, last access: 5 August 2019.

Walters, W., Hyde, E. R., Berg-lyons, D., Ackermann, G., Humphrey, G., Parada, A., Gilbert, J. A., and Jansson, J. K.: Transcribed Spacer Marker Gene Primers for Microbial Community Surveys, Am. Soc. Microbiol., 1, 1-10, https://doi.org/10.1128/mSystems.00009-15, 2015.

Wang, Z., Guo, F., Liu, L., and Zhang, T.: Evidence of Carbon Fixation Pathway in a Bacterium from Candidate Phylum SBR1093 Revealed with Genomic Analysis, Plos One, 9, e109571, https://doi.org/10.1371/journal.pone.0109571, 2014.

Weber, K. A., Urrutia, M. M., Churchill, P. F., Kukkadapu, R. K., and Roden, E. E.: Anaerobic redox cycling of iron by freshwater sediment microorganisms, Environ. Microbiol., 8, 100-113, https://doi.org/10.1111/j.1462-2920.2005.00873.x, 2006.

Whiticar, M. J.: Carbon and hydrogen isotope systematics of bacterial formation and oxidation of methane, Chem. Geol., 161, 291314, https://doi.org/10.1016/S0009-2541(99)00092-3, 1999.

Wurgaft, E., Findlay, A. J., Vigderovich, H., Herut, B., and Sivan, O.: Sulfate reduction rates in the sediments of the Mediterranean continental shelf inferred from combined dissolved inorganic carbon and total alkalinity profiles, Mar. Chem., 211, 64-74, https://doi.org/10.1016/j.marchem.2019.03.004, 2019.

Yan, Z., Joshi, P., Gorski, C. A., and Ferry, J. G.: A biochemical framework for anaerobic oxidation of methane driven by $\mathrm{Fe}(\mathrm{III})-$ dependent respiration, Nat. Commun., 9, 1642 , https://doi.org/10.1038/s41467-018-04097-9, 2018.

Yu, T., Wu, W., Liang, W., Alexander, M., and Hinrichs, K.: Growth of sedimentary Bathyarchaeota on lignin as an energy source, P. Natl. Acad. Sci. USA, 115, 6022-6027, https://doi.org/10.1073/pnas.1718854115, 2018.

Zehnder, A. J. B. and Brock, T. D.: Anaerobic methane oxidation: Occurrence and ecology, Appl. Environ. Microbiol., 39, 194204, 1980.

Zhang, C. L. and Lanoil, B.: Geomicrobiology and biogeochemistry of gas hydrates and cold seeps, Chemocal Geol., 205, 187-194, https://doi.org/10.1016/j.chemgeo.2004.01.001, 2004.

Zhang, J., Dong, H., Liu, D., Fischer, T. B., Wang, S., and Huang, L.: Microbial reduction of $\mathrm{Fe}(\mathrm{III})$ in illite-smectite minerals by methanogen Methanosarcina mazei, Chem. Geol., 292-293, 3544, https://doi.org/10.1016/j.chemgeo.2011.11.003, 2012.

Zhang, J., Dong, H., Liu, D., and Agrawal, A.: Microbial reduction of $\mathrm{Fe}(\mathrm{III})$ in smectite minerals by ther- 
mophilic methanogen Methanothermobacter thermautotrophicus, Geochim. Cosmochim. Ac., 106, 203-215, https://doi.org/10.1016/j.gca.2012.12.031, 2013.
Zhou, Z., Pan, J., Wang, F., Gu, J., and Li, M.: Bathyarchaeota?: globally distributed metabolic generalists in anoxic environments, FEMS Microbiol. Rev., 42, 639-655, https://doi.org/10.1093/femsre/fuy023, 2018. 